\title{
Taxonomy of Cyrtochilum-alliance (Orchidaceae) in the light of molecular and morphological data
}

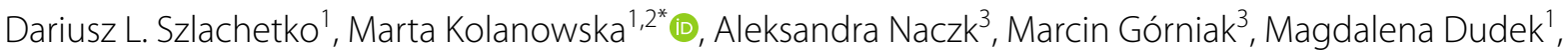 \\ Piotr Rutkowski ${ }^{1}$ and Guy Chiron ${ }^{4}$
}

\begin{abstract}
Background: The generic separateness and specific composition of the orchid genus Cyrtochilum was discussed for almost two centuries. Over the years several smaller taxa were segregated from this taxon, but their separateness was recently questioned based on molecular studies outcomes. The aim of our study was to revise concepts of morphological-based generic delimitation in Cyrtochilum-alliance and to compare it with the results of genetic analysis. We used phylogenetic framework in combination with phenetical analysis to provide proposal of the generic delimitation within Cyrtochilum-alliance. Two molecular markers, ITS and matK were used to construct phylogenetic tree. A total of over 5000 herbarium specimens were included in the morphological examination and the phenetical analysis included 29 generative and vegetative characters.
\end{abstract}

Results: Comparative morphology of the previously recognized genera: Buesiella, Dasyglossum, Neodryas, Rusbyella, Siederella and Trigonochilum is presented. A new species within the the latter genus is described. Fourteen new combinations are proposed. The key to the identification of the genera of the Cyrtochilum-alliance and morphological characteristics of each genus are provided.

Conclusions: A total of six separated genera are recognized within Cyrtochilum-alliance. The reasons of the incompatibility between morphological differences observed within studied taxa and phylogenetic tree are argued and the taxonomic implications of such inconsistency, resulting in fragmentation or lumping of taxonomic units, are discussed.

Keywords: Cyrtochilum, Monophyly, New combinations, New species, Oncidiinae, Paraphyly, Taxonomy

\section{Background}

The genus Cyrtochilum was proposed in 1816 by German botanist C.S. Kunth along with descriptions of two new species, Cyrtochilum flexuosum Kunth and Cyrtochilum undulatum Kunth. Neither was designated as the generitype, which was standard procedure at that time. $C$. undulatum was selected as the type species of the genus by Garay (1974). Since its description, Cyrtochilum has been incorporated into the widely circumscribed genera Oncidium Sw. or Odontoglossum Kunth. by most

\footnotetext{
*Correspondence: martakolanowska@wp.pl

1 Department of Plant Taxonomy and Nature Conservation, The University of Gdańsk, ul. Wita Stwosza 59, 80-308 Gdańsk, Poland

Full list of author information is available at the end of the article
}

subsequent taxonomists. The only exception was Kraenzlin (1917), who revitalized the genus a hundred years after its first description.

Cyrtochilum once again became lost for over 80 years till Dalström (2001) reevaluated it and proposed several new nomenclatural combinations. The generitype determines somewhat the generic delimitation. According to this, Cyrtochilum should comprise species with flexuose, branching inflorescence, large flowers with broad, unguiculate sepals and petals, and narrow, slender lips covered in the basal part by large, massive, composed callus consisting of keels and digitate segments, and partially connate with a clavate, slender gynostemium, forming a right angle with the lip (Fig. 1). 


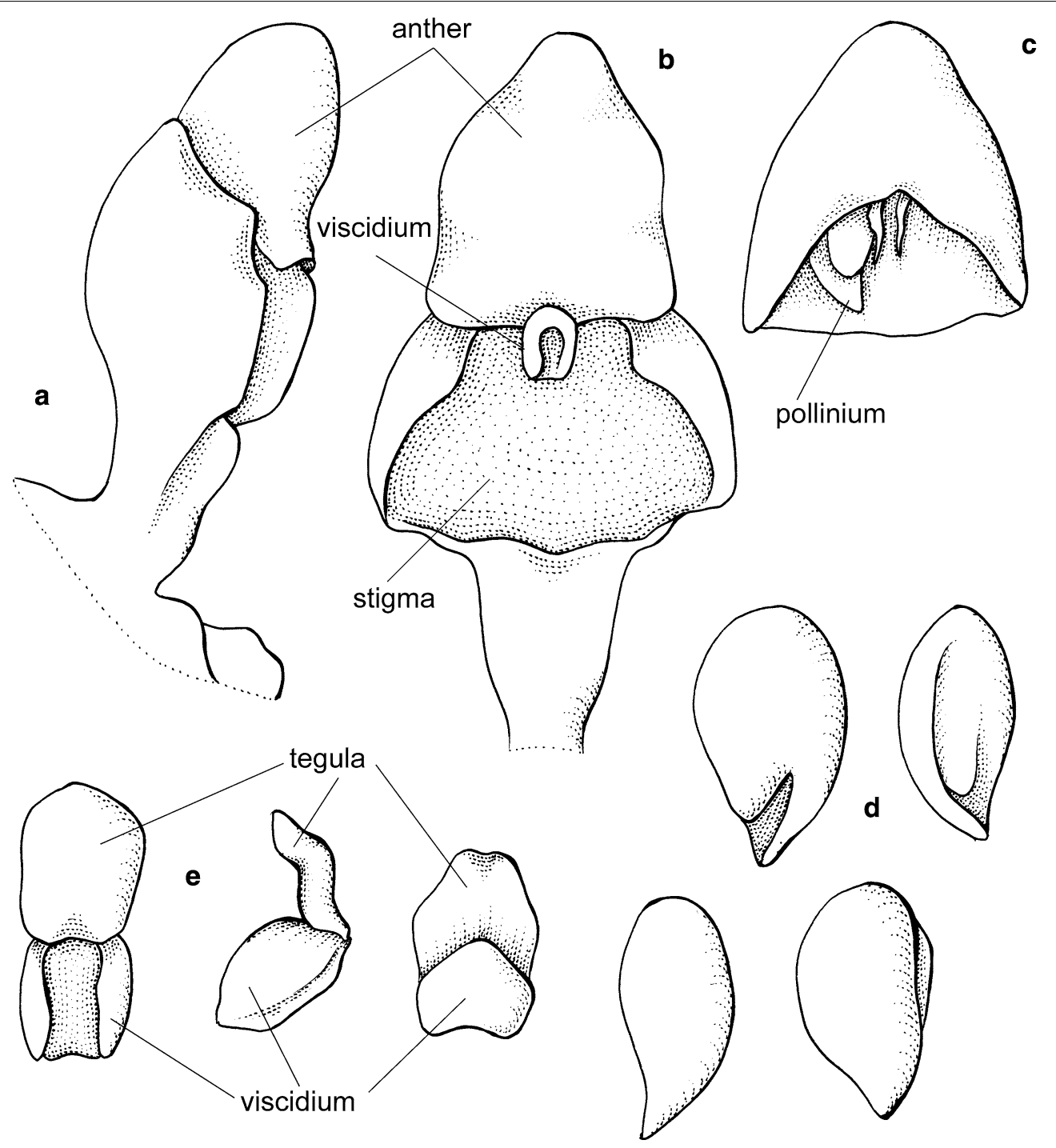

Fig. 1 Cyrtochilum volubile. a Gynostemium, side view. b Gynostemium, bottom view. c Anther. d Pollinia, various views. e Tegula and viscidium, various views (Szlachetko \& Mytnik-Ejsmont 2009)

On the basis of the sequences of molecular markers Neubig et al. (2012) proposed another circumscription of the genus. The authors included here various species, for example Odontoglossum myanthum Lindl. (generitype of Dasyglossum Königer \& Schildh.), Cyrtochilum flexuosum Kunth (generitype of Trigonochilum Königer \& Schildh.), Oncidium aureum Lindl. (generitype of Siederella Szlach., Mytnik, Górniak \& Romowicz), as well as rspresentatives of Rusbyella, Buesiella, Neodryas and Odontoglossum. All of them inhabit mainly Ecuadorian Andes with many species also found in Colombian and northern Peruvian mountains. Neubig et al. (2012) created a monophyletic but highly heteromorphic unit, what resulted in the very enigmatic description of the genus (cf. Pridgeon et al. 2009; Dalström 2010).
The aim of presented study was to evaluate and compare morphological differences between taxa of Cyrtochilum-complex with the outcomes of molecular studies.

\section{Methods}

\section{Morphological study}

A total of over 5000 herbarium and liquid preserved specimens of orchids representing Cyrtochilum s.l. and related oncidioid genera and deposited in AMES, AMO, B, BM, C, COL, CUVC, F, FLAS, HUA, JAUM, K, MO, NY, P, PMA, UGDA, VALLE and W (Thiers 2015) were examined according to the standard procedures (database of specimens representing Cyrtochilum s.l. and Odontoglossum is provided in Additional file 1: Appendix S1). Every studied specimen was photographed and the data 
from the labels were taken. Both vegetative and generative characters of each plant were examined (the shape and size of the pseudobulbs, leaves, inflorescence architecture, shape and size of the floral bracts, flower morphology and gynostemium structure) and compared with existing type material of the most of distinguished species of the subtribe. The nomenclature of morphological characters follows Dressler (1981) and Szlachetko (1995).

\section{Phenetical analysis}

Phenetical studies were employed based on 29 characteristics describing the taxonomically important generative and vegetative structures of Cyrtochilum species exploited by Neubig et al. (2012). As an outgroup we selected Odontoglossum epidendroides, a generitype of the genus Odontoglossum. A complete list of these features, as well as selected sets, is given in Additional file 2: Appendix S2. We have used a binary, 0-1, system of coding characteristics, because it is unambiguous and the most often applied in phenetic analyses. The incorporation of each feature for every Cyrtochilum s.l. species has resulted in a data matrix containing 1247 characteristics. To create hierarchic phenograms we used the PAST program (Hammer and Harper Ryan 2001). The so-called cluster analysis process is a typical method of analysis used in phenetic research (Stace 1989). We created a distance matrix using the Manhattan measure (Domański and Kęsy 2005; Pandit and Gupta 2011; Madhulatha 2012), which is an average subtraction measured across the dimensions $\mathrm{D}=\Sigma \mathrm{i} \mid \mathrm{Xij}-\mathrm{Xik}$. We have also used the "middle links rule unweighted pair-group average" (UPGMA) as an amalgamation rule. The resulting phenograms were compared with the results of research conducted by Neubig et al. (2012).

\section{Molecular analyses \\ Taxon sampling}

For the molecular analyses 91 specimens representing genus Cyrtochilum. The outgroup includes one species, Odontoglossum epidendroides. Sequences of outgroup taxa and for the most representatives of Cyrtochilum were downloaded from GenBank (Additional file 3: Appendix S3). DNA sequences of Cyrtochilum volubile were obtained in laboratory on the Department of Plant Taxonomy and Nature Conservation University of Gdansk. Sequences for both markers (ITS, matK) were deposited in GenBank. Accession number and information about collector were place in Additional file 3: Appendix S3.

\section{Molecular markers}

Nucleotide sequences from one nuclear (ITS) and one plastid (matK) genome region were used in the molecular analyses. The ITS region consisted of the $18 \mathrm{~S}$ and $26 \mathrm{~S}$ ribosomal RNA genes, respectively the internal transcribed spacers (ITS1, ITS2) and the intervening gene 5.8S. For the sample of Cyrtochilum volubile was amplified part of the ITS region (ITS1 - 5.8S - ITS2) using the primers $101 \mathrm{~F}$ and 102R (Douzery et al. 1999). For the mat $\mathrm{K}$ gene, we amplified fragment of approximately $1400 \mathrm{bp}$ using the primers 19F (5'CGTTCTGACCATATTGCACTATG3') from Molvary et al. (2000) and 1326R (5'TCTAGCACACGAAAGTCGAAGT3') from Cuénoud et al. (2002).

\section{DNA extraction, amplification and sequencing}

DNA was extracted using the Sherlock AX Kit (A\&A Biotechnology, Poland) following manufacturer protocol. For the sample homogenization were used precooled in $-45{ }^{\circ} \mathrm{C}$ lysing Matrix A tube and FastPrep instrument (MP Biomedicals, USA). Pellet of DNA was resuspended in $50 \mu \mathrm{l}$ of TE buffer.

Amplifications and sequencing were using Eppendorf and Biometra TGradient thermal cyclers. PCR reaction for the both markers (ITS, matK) were performed in a total volume of $25 \mu \mathrm{l}$ containing $1 \mu \mathrm{l}$ temple DNA ( 10-100 ng), $0.5 \mu \mathrm{l}$ of $10 \mu \mathrm{M}$ of each primers, $12.0 \mu \mathrm{l}$ Start Warm 2X PCR Master Mix (A\&A Biotechnology, Poland), water and/or $1.0 \mu \mathrm{l}$ dimethyl sulfoxide (DMSO) to ITS region $/ 0.5 \mu \mathrm{l} 25 \mathrm{mM} \mathrm{MgCl} 2$ only to matK marker. Amplification parameters for nrITS (ITS1 + 5.8S + ITS2) were: $94{ }^{\circ} \mathrm{C}, 4 \mathrm{~min}$; $30 \mathrm{X}\left(94{ }^{\circ} \mathrm{C}, 45 \mathrm{~s} ; 52{ }^{\circ} \mathrm{C}, 45 \mathrm{~s} ; 72{ }^{\circ} \mathrm{C}\right.$, $1 \mathrm{~min}) ; 72{ }^{\circ} \mathrm{C}, 7 \mathrm{~min}$. For the part of mat $\mathrm{K}$ gene were: $95{ }^{\circ} \mathrm{C}, 3 \mathrm{~min} ; 33 \mathrm{X}\left(94{ }^{\circ} \mathrm{C}, 45 \mathrm{~s} ; 52{ }^{\circ} \mathrm{C}, 45 \mathrm{~s}, 72{ }^{\circ} \mathrm{C}, 2 \mathrm{~min}\right.$ $30 \mathrm{~s}) ; 72^{\circ} \mathrm{C}, 7 \mathrm{~min}$. Wizaed SvGel and PCR Clean Up System (Promega, US) was used to clean PCR products following manufacturer protocol. Purified products of PCR reaction were cycle-sequenced using Big Dye Terminator v 3.1 Cycle Sequencing Kit (Applied Biosystems, Icn., ABI, Warrington, Cheshire, UK). Cycle sequencing parameters were: $95{ }^{\circ} \mathrm{C}, 2 \mathrm{~min} 40 \mathrm{~s} ; 25 \mathrm{X}\left(95{ }^{\circ} \mathrm{C}\right.$, $\left.10 \mathrm{~s} ; 50{ }^{\circ} \mathrm{C}, 10 \mathrm{~s} ; 60{ }^{\circ} \mathrm{C}, 4 \mathrm{~min}\right)$. Total volume sequencing reaction of $10 \mu \mathrm{l}$ containing $1.3 \mu \mathrm{l}$ of $5 \mathrm{X}$ sequencing buffer, $1 \mu \mathrm{l}$ of Big Dye terminator, $0.4 \mu \mathrm{l}$ of $10 \mu \mathrm{M}$ primer (1.6/3.2 pmol), $0.5 \mu \mathrm{l}$ dimethyl sulfoxide (DMSO), $1 \mu \mathrm{l}$ of amplified product (30-90 $\mathrm{ng} / \mu \mathrm{l})$ and water. The sequencing reaction products were then purified and sequenced on an ABI 3720 automated capillary DNA sequencer in the Genomed S. A (Warsaw, Poland). DNA sequences chromatograms were inspected/edited in FintchTV and assembled using AutoAssembler (Applied Biosystems, Inc). Sequences for the Cyrtochilum volubile were deposited in GenBank (see Additional file 3: Appendix S3).

\section{Data analyses}

The consensus sequences, both ITS region and part of mat $\mathrm{K}$ gene, were done automatically alignment by 
Seaview (Galtier et al. 1996) using algorithm MUSCLE (Edgar 2004). Analyses were performed separately on the matrix of each marker separately using PAUP*4.0b10 (Swofford 2002) and MrBayes 3.1.2 (Ronquist and Huelsenbeck 2003).

Maximum parsimony analysis (MP) used a heuristic search strategy with tree-bisection-reconnection (TBR) branch swapping and the MULTREES option in effect, simple addition and ACCTRAN optimization. Gaps were treated as a missing value. All characters were unordered and equally weighted (Fitch 1971). Internal support of clades was evaluated by character bootstrapping (Felsenstein 1985) using 1000 replicates. For bootstrap support levels, we considered bootstrap percentages (BP) of $50-70 \%$ as weak, $71-85 \%$ as moderate and $>85 \%$ as strong (Kores et al. 2001). We also performed a Bayesian inference (BA). An evolutionary model for each region (ITS, matK) was calculated with MrModeltest 2.2 (Nylander 2004). For the both data matrix the GTR + I + G model was selected according to the AIC (Akaike Information Criterion). For analyses, two simultaneous runs of four chains each were carried out with the MCMC algorithm, for 10,000,000 generations, sampling one tree for each 100 , until the average standard deviation of split ranges was smaller than 0.01 . After discarding the initial $25 \%$ trees of each chain as the burnin. Majority rule consensus tree was generation for the remaining trees in PAUP to assess topology and clades posterior probabilities (PP). Value of PP in Bayesian analysis are not equivalent to BP, generally are much higher (Erixon et al. 2003).

\section{Results}

\section{Morphological analyses}

The phenetic similarity of the studied species based on morphological data is presented in Fig. 2. The first group comprises species usually classified to the genus Dasyglossum along with Neodryas/Buesiella. The species in this complex are characterized by subsimilar tepals, usually free sepals, an entire or 3-lobed lip, united basally with the base of the column, and parellal to it. The upper part of the lip is geniculate and often retrorse. The lip callus is simple, consisting of a pair of fleshy, parallel, adjoining tori, diverging in front, mostly enclosed by the thickened flanks of the gynostemium. The gynostemium is rather short, robust, in the upper half gently upcurved or straight. The generic borderline between Dasyglossum and Neodryas/Buesiella mostly concerns the character of the lip callus, which is large and variously lobed in the latter.

The next group includes Cyrtochilum species, such as "C. ioplocon", "C. ramosissimum", "C. revolutum", " $C$. angustatum" and "C. pardinum". All of these species are characterised by rather narrow, acuminate tepals with more or less undulate margins and somewhat twisted apices. Sepals and petals are dissimilar in form. Sepals have long and narrow claw, and petals-relatively short and wide. Lip is sessile, basally parallel to the gynostemium, and then geniculate bent down, the lamina is oblanceolate to oblong obovate in general outline, with acuminate and twisted apex. Lip calli consist of a pair of rather large basal wings with additional digitate or clavate projections below them. Gynostemium is erect, only basally connate with the lip, cylindrical, without any additional projections at the apex or at the base of the stigma. Floral bracts are usually shorter than half of pedicellate ovary. These species are mingled with Odontoglossum epidendroides and "C. macasense". The former species is the type of the genus. Tepals of Odontoglossum are usually subsimilar, either set on prominent claw, or subsessile, but in both situations the claw of sepals and petals are similar. Margins of tepals are smooth, often crispate, and rarely undulate. Lip is basally connate with the gynostemium. In $O$. epidendroides the fusion is prominent and can reach onefifth of the total lip length. Basal part of the lip is clawed, and lamina is more or less perpendicular to it. The shape of the lamina varies - usually it is oblanceolate to elliptic, often with crispate margins and long acuminate apex. Lip calli form a complicated pattern and consist of numerous digitate or lamellar projections, glabrous or ciliate. The gynostemium is usually somewhat arcuate, and form with the column an acute angle. It is apically adorned by various, filiform, digitate or lamellar projections. Floral bracts are prominently shorter than pedicellate ovary.

"C. macasense" is characterised by subsimilar, shortly clawed tepals, and sessile lip, which is prominently 3-lobed. The lip calli is compoused of two pairs of fleshy ridges of various lengths. The shorter pair is bilobed. Gynostemium forms an acute angle with the lip, and is erect, relatively short and massive, without any prominent appendages.

The "C. midas" group embraces species with small usually dull-coloured flowers, brownish or greenish-brown, which are usually treated as Trigonochilum. Tepals are rather dissimilar, sepals are narrower, with narrow claw, and petals are wider, short-clawed. The lip is triangularcordate, sessile, diverging from the gynostemium at $70^{\circ}-90^{\circ}$ with a simple, torous, sometimes verrucose or gibbous callus. The lip lamina is centrally convex. The form and position of the gynostemium versus the lip in the species of this group is somewhat similar to Cyrtochilum s.str. It is usually elongate, basally much expanded and connate with the lip, slightly sigmoid or upcurved, slender, and the tegula has a prominent roof-like projection on the inner surface above the viscidium. We did not observe this character in any other species of the Cyrtochilum-clade. Floral bracts are rudimentary, much 


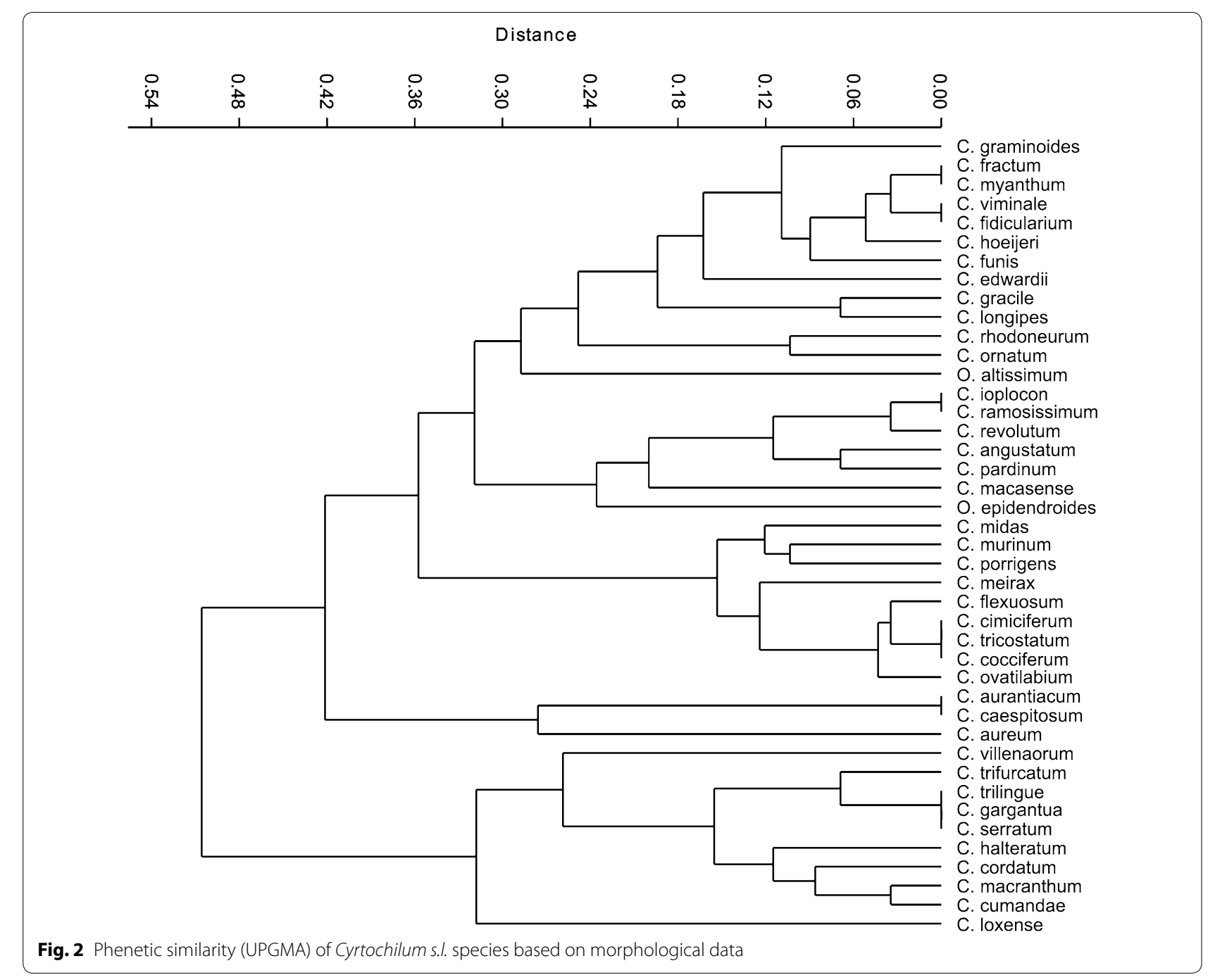

shorter than pedicellate ovary. Trigonochilum species are rarely confused with other genera, although the species boundaries are often not clear.

"C. aurantiacum/caespitosum" is rather an isolated group, at least as morphology is considered. Both are easily recognisable by the lip structure which has narrow, lower part, more or less canaliculated, with prominent rather simple calli. The apical part of the lip is much expanded forming transversely elliptic lamina. The gynostemium is somewhat similar to that one of Dasyglossum, i.e. it is erect, narrowly winged, apically upcurved. What is interesting tegula is narrow, linear 3-4 times longer than viscidium. Both species are included in the genus Rusbyella. Interestingly, "C. aureum" is linked to this group, although the gynostemium structure of " $C$. aureum" can suggest the affinity of this species to Cyrtochilum s.str. The short gynostemium is clavate, somewhat arcuate, with oblong-obovate projections with fringed margins. The gynostemium forms an acute angle with the lip. The lip reminds somewhat " $C$. loxense", i.e. it is clawed, lamina is flat or convex, obscurely 3-lobed or pentagonal in outline, lip calli is missing to prominent, and contain of series of small projections in two rows. Lateral sepals are connate almost to the apex.

The last group contains those species which are included in the genus Cyrtochilum s.str. The common character of those species is gynostemium, gently sigmoid, basally prominently connate with the lip, elongated and slender above. The erect part is clavate and forms a right angle with the lip. The column part is slightly thickened just above the base, with two wing-like or digitate projections just below the stigma. Tepals are dissimilar, usually shield-like, obtuse to rounded apically, often undulate. Sepals have long and narrow claw, and petals-short and wide. At the base of the sepals' claw winglike appendices can be observed in most of the species. 
The lip of Cyrtochilum s.str. is sessile to shortly clawed, and usually divided into expanded and convex basal part and usually narrow, ligulate, pendent apical part. The lip calli is much complicated and usually consist of massive and variously lobed central part, with various number of additional projections spread all over the basal part. The floral bracts are large, leafy, nearly half as long as pedicellate ovary.

"C. villenaorum" is different from the species described above by the subsessile lip which has very large lamina, unequally 3-lobed, the middle lobe is more or less transversely elliptic in outline, with relatively small and simple calli with the middle lobe being somewhat upcurved. The gynostemium is devoid of any projections. Regarding morphology, "C. volubile" is very similar to " $C$. villenaorum", but we did not include the former species in our analysis.

Morphologically distinct species in Cyrtochilum s.str. is "C. loxense". Its tepals are subsimilar, shortly clawed; lateral sepals are connate in the basal fifth or so. Lip is straight, clawed, lamina is very unequally 3-lobed, with both lateral lobes relatively small, and the middle lobe very large, transversely elliptic with truncate apex. The calli is rather obscure and consist of series of irregular small projections near the lip base. The gynostemium is perpendicular to the lip, somewhat arcuate, basally connate with the lip claw, with short digital projections near the stigma.

\section{Molecular analyses}

Statistcs for the data matrices (ITS, matK) are separated by "/". The number of analyzed taxa was $80 / 65$ respectively. The aligned length of the matrix was $779 / 1303$ characters of which $88 / 70$ were parsimony informative. The number of the most parsimonious trees were $>10.000$, tree-length was $219 / 181$, consistency index $(\mathrm{CI})=0.76 / 0.83$ and retention index $(\mathrm{RI})=0.89 / 0.90$. Consensus trees of Bayesian analysis are presented in Figs. 3 and 4.

Topology of MP trees and Bayesian trees are similar. The clades that have low bootstrap support or/and collapse in the strict consensus tree in parsimony analysis often appeared in Bayesian trees with low posterior probabilities too. One of the most parsimonious trees is available from the corresponding author. The combined phylogenetic tree presented by Neubig et al. (2012) is based on the analyses of five DNA regions (ITS, trnH$p s b A, 5^{\prime} y c f 1,3^{\prime} y c f 1$, matK).

The first subclade comprises the species of Cyrtochilum s.str. (Fig. 5) and "C. ramosissimum", and is sister to the next subclade including two species-" $C$. angustatum" (Fig. 6) and "C. pardinum". The last three aforementioned species resemble Odontoglossum typified by
Odontoglossum epidendroides Kunth and, in fact, they have usually been assigned to that genus. It is noteworthy that Odontoglossum epidendroides is embedded in a separate clade (Fig. 7) and treated by Neubig et al. (2012) as a member of Oncidium s.l.. All the Odontoglossum-like species of Cyrtochilum mentioned above share a series of mutual features with Odontoglossum, i.a. gynostemium is slender, erect, forms an acute angle with a narrow lip, and it is fused with it along the midline at the base, creating two basal cavities (Fig. 8). The lip is geniculately bent near the middle exposing multiple calli consisting of narrow, digitate and/or filiform projections. Sepals and petals are narrow and undulate on margins, and sepals are prominently clawed.

In our matK tree species constituting this subclade form two groups A and B with posterior propability value 53 and 81, respectively. Group B comprises also C. volubile and C. villenaorum. The ITS tree does not solve relations between particular groups of species, although some branches are relatively highly or highly supported, e.g. Cyrtochilum angustatum-C. pardinum (e) with BS/PP $=62 / 100$. Most other species of Cyrtochilum s.str. (a) are grouped together with BS/ $\mathrm{PP}=55 / 80$.

The subclade "Cyrtochilum myanthum" includes species classified in Dasyglossum (Fig. 9), the genus established by Königer and Schildhauer (1994) and typified with Odontoglossum myanthum Lindl. The key characters of the genus mentioned by the authors are a simple callus, consisting of a pair of fleshy ridges and the lower half of the lip being parallel with the gynostemium, and apically part geniculately bent. Additionally, all species possess a massive, erect gynostemium, prominently winged and lateral sepals being free to the base (Fig. 10). The gynostemium and channeled lip callus form a kind of tube accessible to long-beaked pollinators.

The position of "C. edwardii" which is sister to Dasyglossum sublcade is unexpected, as it shares characters of the genus Trigonochilum rather than Dasyglossum, i.e. lip callus consisting of 7 massive projections confined to the central part of lamina, lip being arcuately bent down, and gynostemium and lip form a right angle. The colour of the flower, however, is unique for Dasyglossum/Trigonochilum alliance and is deep purple or lilac and lip callus is bright yellow. The gynostemium just below stigma is adorned with a pair of wing-like projections, not found in Dasyglossum.

It is interesting to note a position of "C. flexuosum". The species is nested in two different places in cladogram; the first one is polytomic with Dasyglossum and "C. edwardii", and the other one is embedded in Trigonochilum subclade. As the species is generitype of Trigonochilum we discuss it below. 


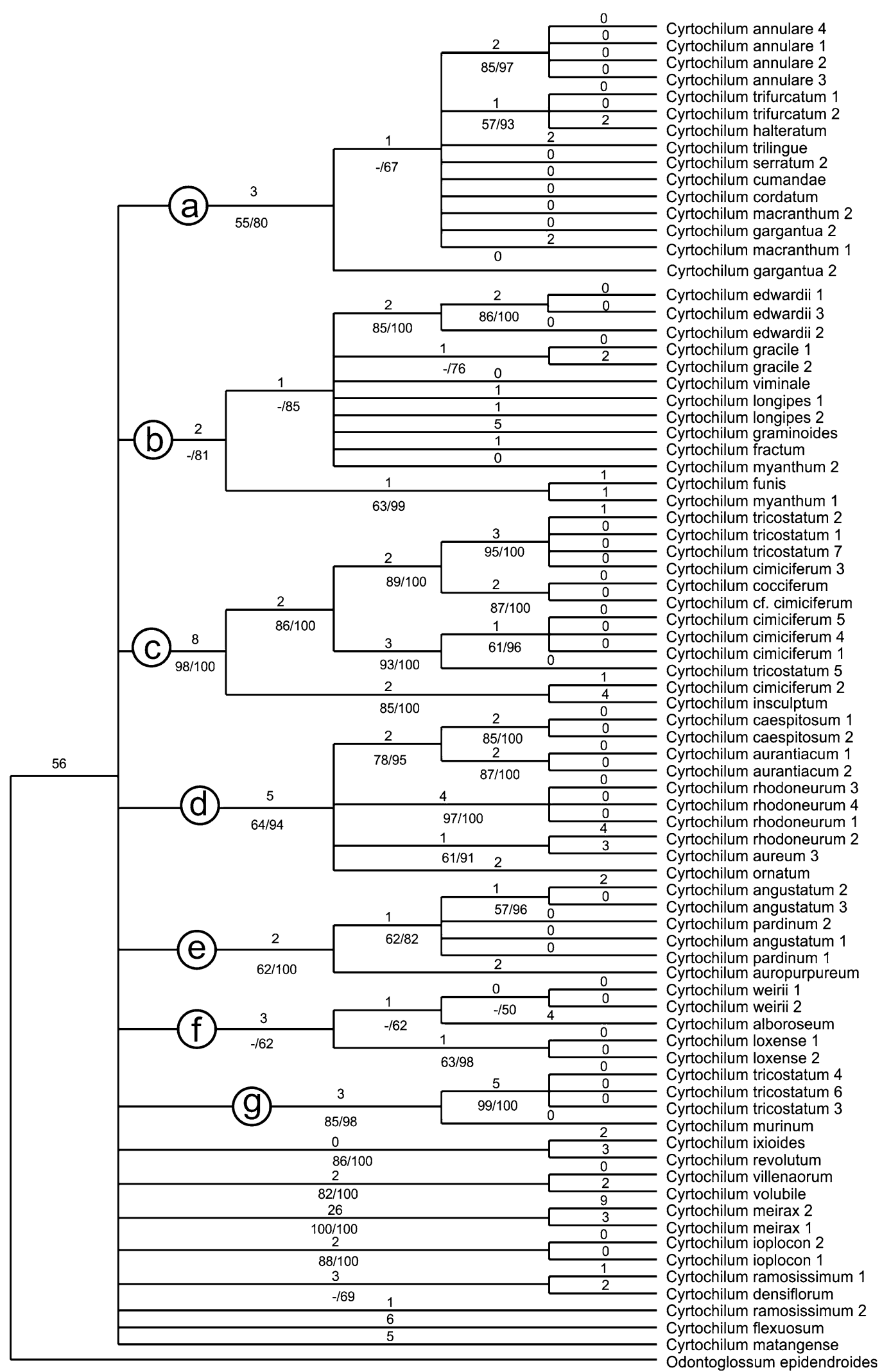

Fig. 3 Bayesian 50\% majority-rule tree for genus Cyrtochilum from ITS1-5.8S-ITS2 sequences. The numbers below the branches are bootstrap percentages (BP) and posterior probability (PP), bootstrap percentages $\geq 50 \%$ are given for supported clades. The branches length is shown above 


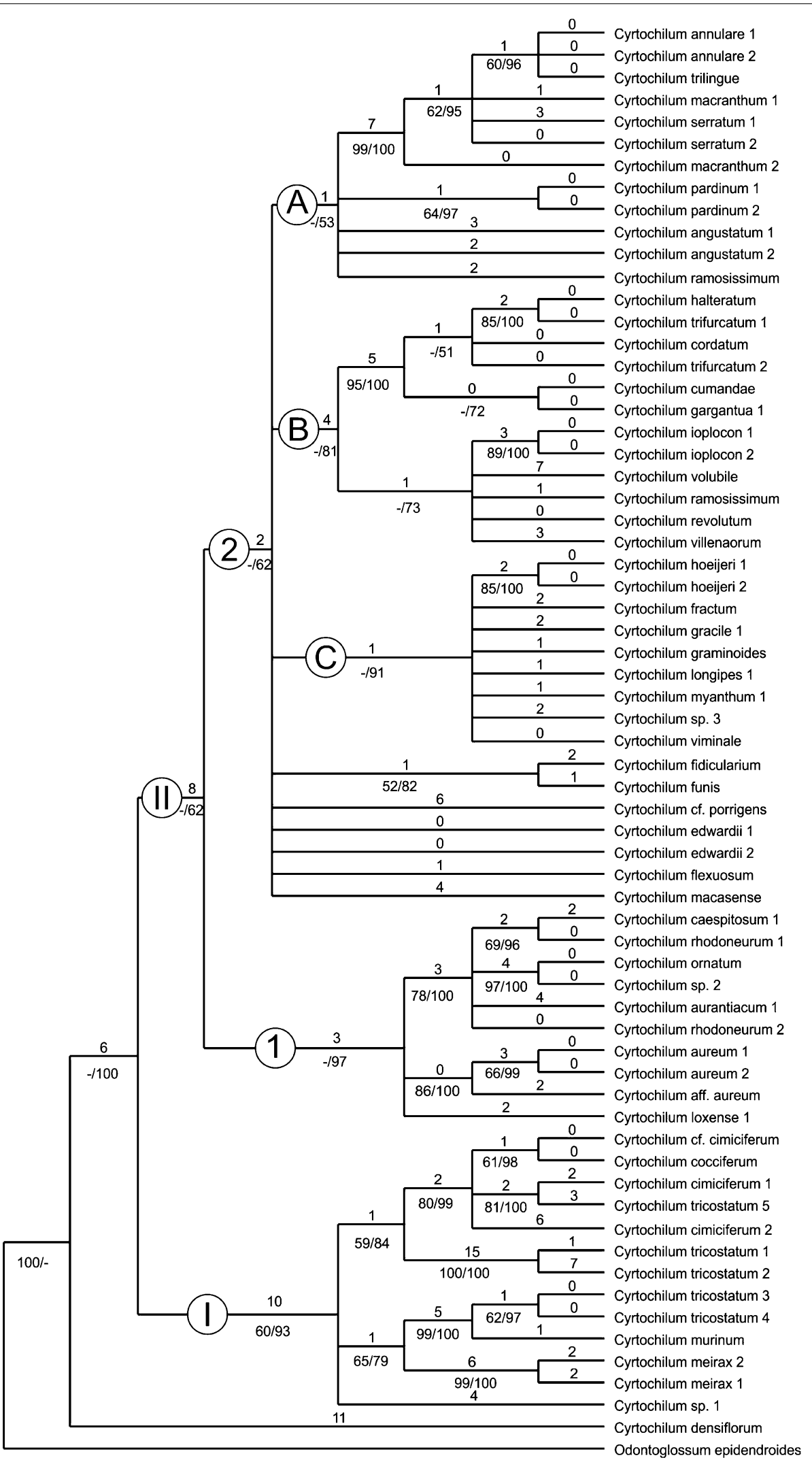

Fig. 4 Majority-rule consensus of 7500 trees obtained in Bayesian analysis of matK gene for genus Cyrtochilum. Values below branches represent bootstrap support $(\geq 50 \%)$ from 1000 replicates and posteriori probabilities ( $\geq 50 \%)(\mathrm{BP} / \mathrm{PP})$. The branches length is shown above 


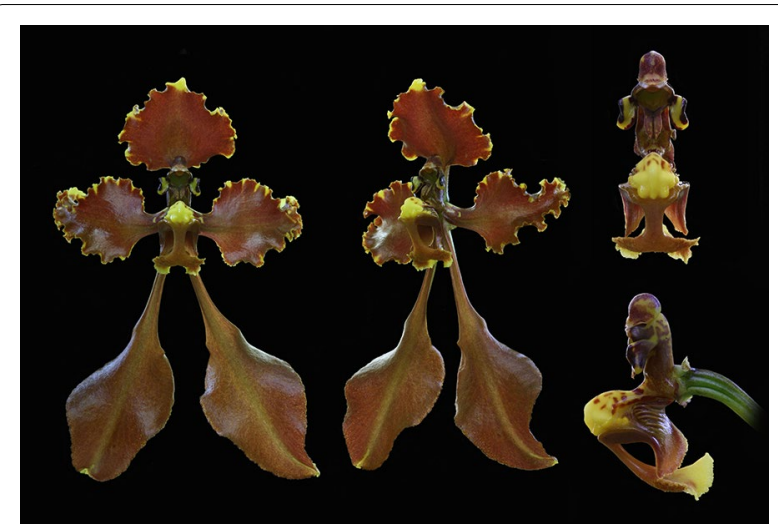

Fig. 5 Cyrtochilum cryptocopis. Photo: Guido Deburghgraeve

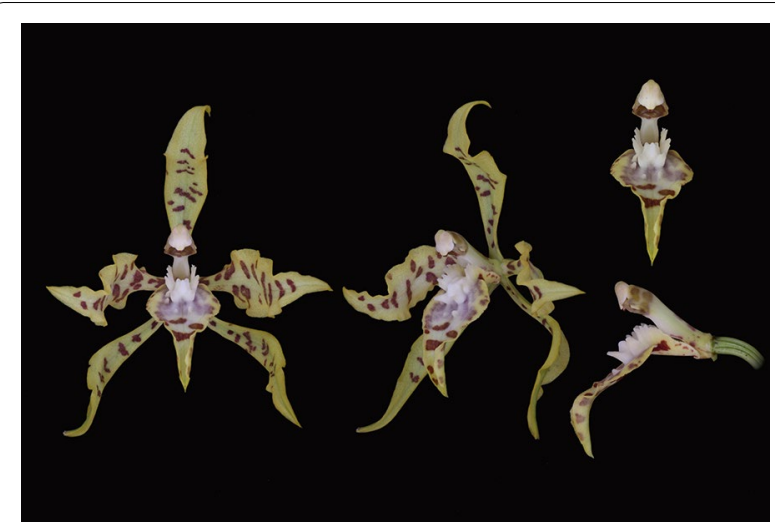

Fig. 6 Odontoglossum angustatum. Photo by Guido Deburghgraeve

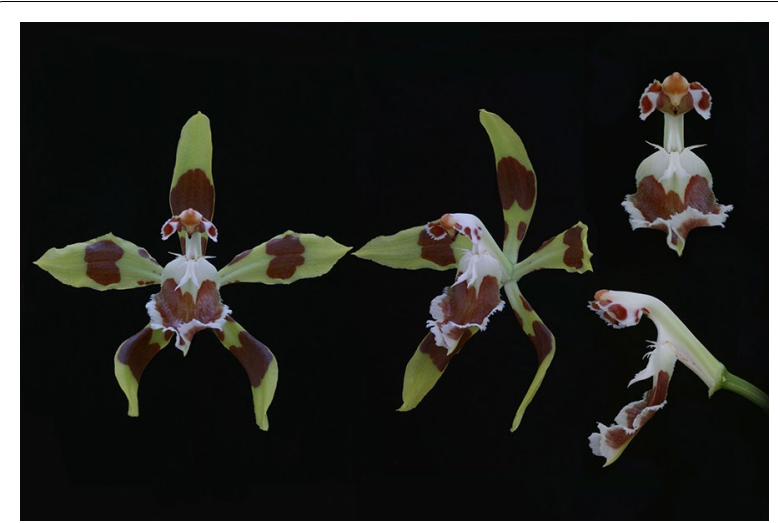

Fig. 7 Odontoglossum epidendroides. Photo by Guido Deburghgraeve

"C. cf. porrigens" is again polytomic to the subclades mentioned above, and "C. macasense" is sister to all aforementioned groups. The first species is similar in all respects to Trigonochilum and has more or less triangular-obovate lip with complexed calli, clavate gynostemium basally connate with the lip and then abruptly upcurved in result forming an obtuse angle with it.The general flower architecture of $C$. macasense" reminds somewhat " $C$. edwardii". The gynostemium and the lip form a right angle, lip callus consists of 4 ridges of various length, of which the shorter pair is bilobed. The colour of the flowers is a mixtre of yellow and brown, likes in Trigonochilum. The unique character of this species is prominently 3-lobed lip with much elongate middle lobe.

The $m a t K$ tree does not solve relation between species of this subclade-some of them-e.g. Cyrtochilum myanthum, C. viminale, C. gracile, etc.-are grouped together (C) and highly supported $(\mathrm{PP}=91)$. The others are polytomic, e.g. C. edwardii, C. macasense or C. flexuosum. All those species form a mutual subclade (b) in the ITS analysis (PP = 81).

The subclade "Cyrtochilum flexuosum" embraces species assigned to the genus Trigonochilum (Fig. 11). The genus was described in 1994 by Königer and Schildhauer to encompass Oncidiinae species characterized by a subtriangular lip diverging from the gynostemium at $70^{\circ}-90^{\circ}$ and a short, stout, clavate gynostemium (Fig. 12) with distinct swellings below the stigma. The lip callus is a large mass of variously, but shallowly lobed tissue occupying the central part of the lamina. The authors designated T. flexuosum (Kunth) Königer \& Schildh. as a generitype and presented a list of 22 species transferred to the newly established taxon from Cyrtochilum Kunth, Odontoglossum Kunth and Oncidium Sw. In the following years, Königer (1996, 1999, 2000) described some new species of Trigonochilum and other species were reassigned to the genus or described by Senghas (2001, 2003). The latter author, however, synonymized all the species of Dasyglossum Königer under Trigonochilum. With some additional transfers made by Königer (2008, 2010) and a description of the new species, the genus currently includes about 60 species with a distribution from Peru and Bolivia to Colombia and Venezuela. The border between them is very often very difficult to define. Dualistic position of "C. flexuosum" on the Neubig et al. (2012) phylogenetic tree is probably caused by misidentification of one of the samples.

The species constituting this subclade are on the mutual branch (I) in matK tree and has 60/93 BS/PP. This branch is sister to all other Cyrtochilum-alliances. The ITS tree analysis gives somewhat different pattern of relation between aforementioned species - this subclade is divided into two groups $\mathrm{c}$ and $\mathrm{g}$, with high bootstrap support and posterior propability-98/100 and 85/98, respectively. Relations between these groups are not solved.

The last subclade of the Cyrtochilum-group is composed of a mixture of species included in various genera, whose common features are more or less connate lateral 


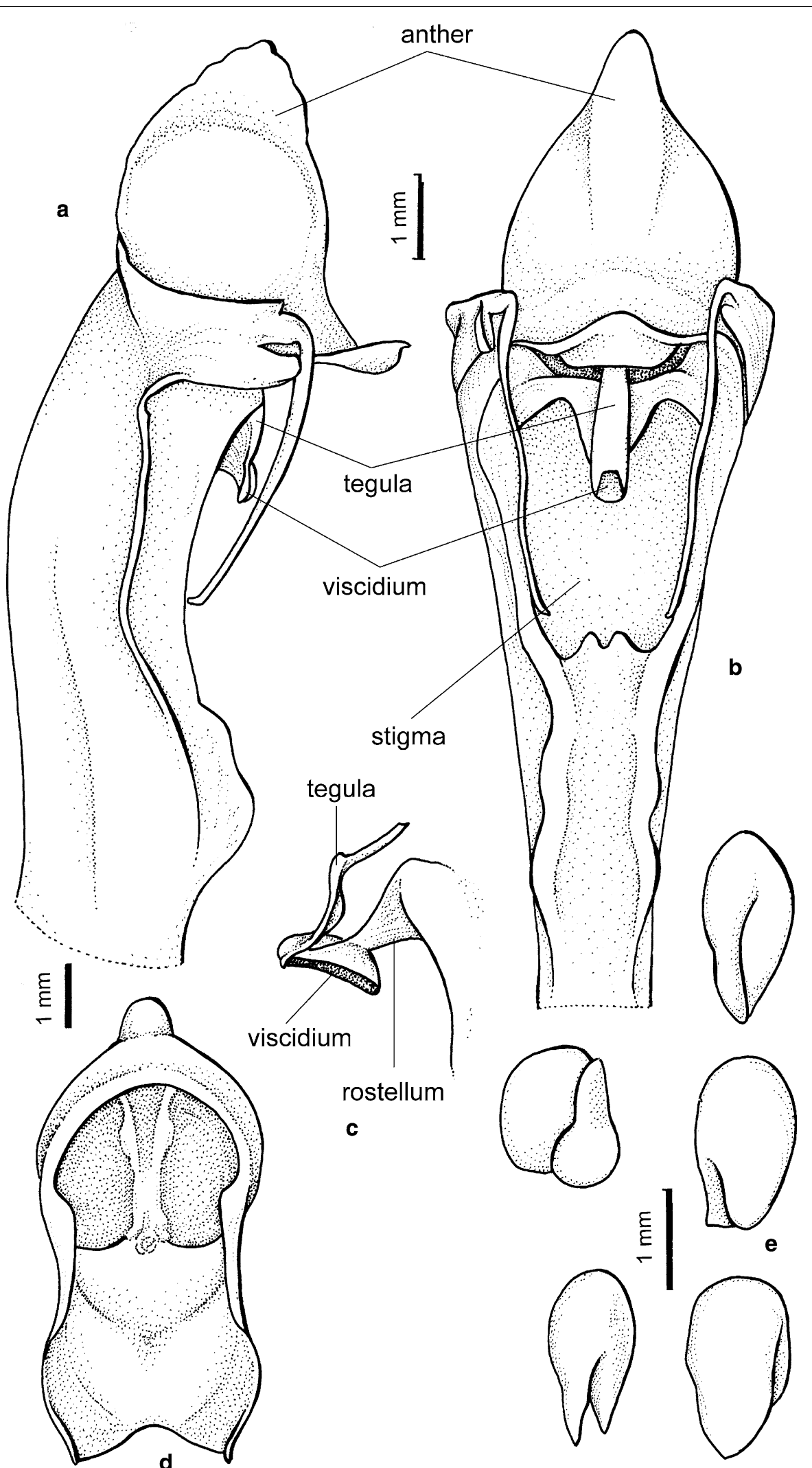

Fig. 8 Odontoglossum odoratum. a Gynostemium, side view. b Gynostemium, bottom view. c Rostellum, side view. d Anther. e Pollinia, various views (Szlachetko \& Mytnik-Ejsmont 2009). 


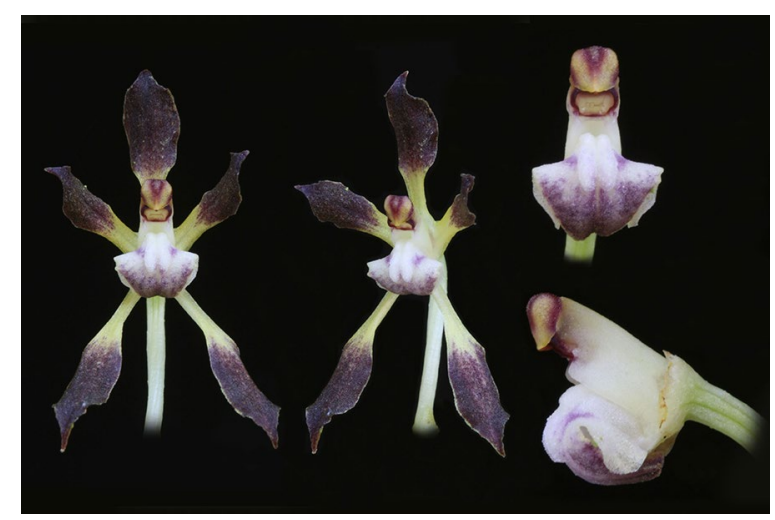

Fig. 9 Dasyglossum myanthum. Photo: Guido Deburghgraeve sepals, stout gynostemium, usually parallel to the lower part of the lip, and bent in the geniculate manner above base. "C. aurantiacum" and "C. caespitosum" are easily distinguishable from all other Cyrtochilum species by their lip structure, i.e. a narrow, canaliculated claw occupied by an oblong callus, expanded apically in transversely elliptic lamina. The gynostemium is straight and apically reflexed. These species have been classified in the genus Rusbyella (Fig. 13). "C. rhodoneurum" differs from the aforementioned species in its oblong-ligulate lip with a prominent central callus. It has been assigned to the genus Neodryas (Figs. 14, 15). "C. ornatum", usually included in the genus Buesiella, are distinguished from the above species by their digitate projections near

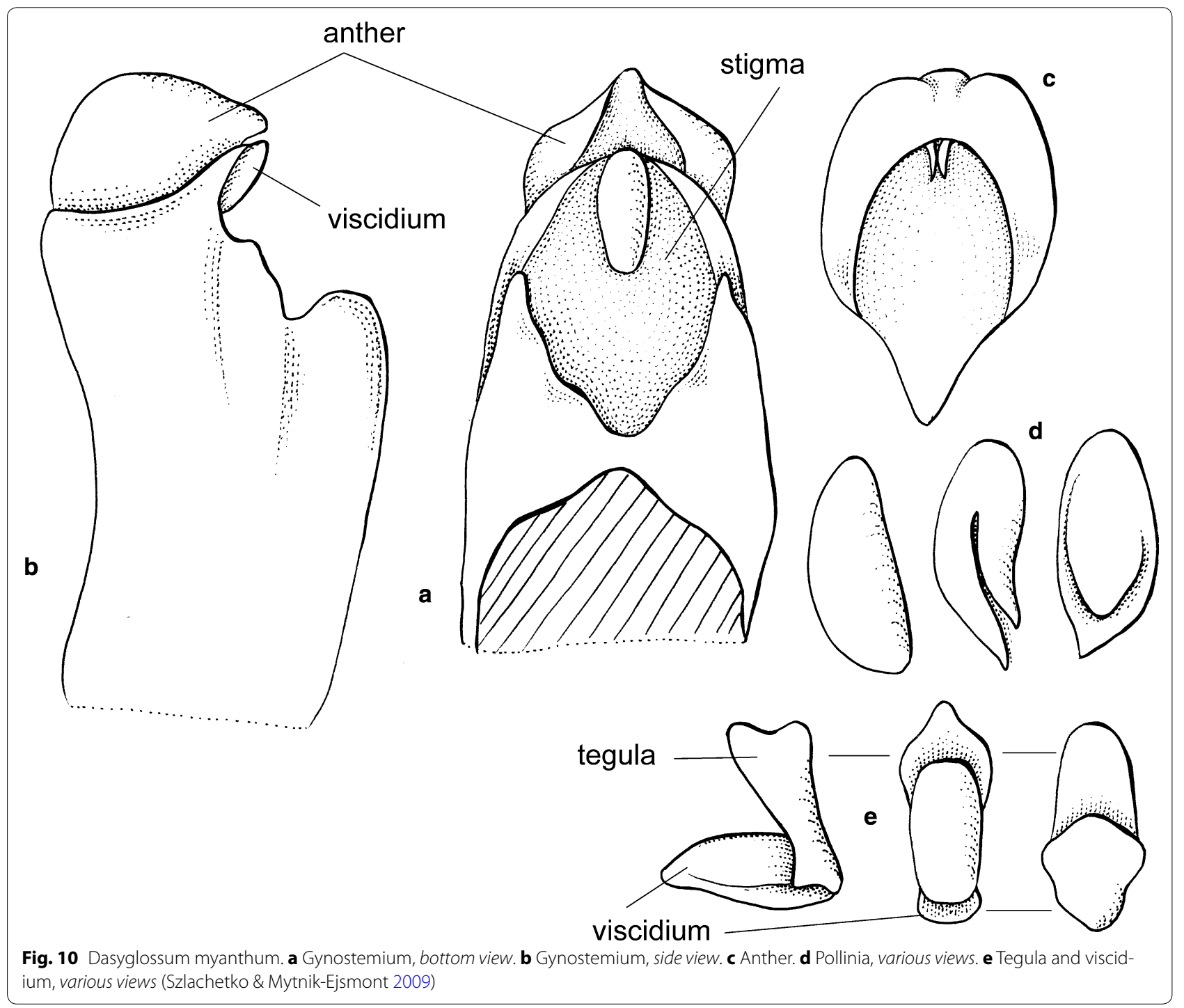




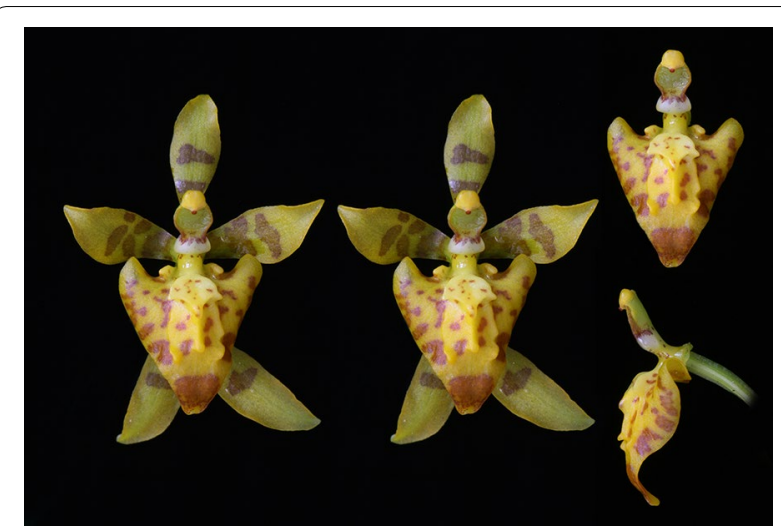

Fig. 11 Trigonochilum meirax. Photo: Guido Deburghgraeve

the receptive surface and a hastate lip. "C. aureum" was the only species of the genus Siederella characterized by a narrowly clawed lip with greatly expanded lamina (Fig. 16), a rather obscure central callus and digitate projections near the stigma (Fig. 17). The gynostemium forms an angle of ca $30^{\circ}$ with the lip (Fig. 18). In both analysed trees based on ITS (d) and matK (1) aforementioned species are grouped together with high PP value94 and 97, respectively. In this case bootstrap suppor is low $(64$ and $<50)$.

The last species in the group is "C. loxense" (Figs. 19, 20), which in habit, type of inflorescence and clawed tepals is reminiscent of Cyrtochilum s.str. Even though its gynostemium is perpendicular to the lip, the labellum is unique in the genus-it is short-clawed, 3-lobed with the middle lobe being the largest, transversely elliptic and concave. The lip callus is relatively small and confined to the basal part of the lip. In matK tree $C$. loxense is attached to C. caespitosum-alliance (1), and in the ITS tree this species is connected with $C$. alboroseum and $C$. weirii (f). In the first case value of posterior propabilty is high (97) and in the second-only 62. The matK shows that $C$. loxense is only distantly related with $C$. villeanorum and C. volubile, with which it is very similar morphologically. The relations between these species are not solved in out ITS analysis.

\section{Discussion}

Until recently, it appeared that DNA fragment sequencing would enable the reconstruction of the phylogeny of organisms with a high degree of accuracy. Almost all data obtained from any sources other than genetic material began to be discarded. Numerous articles presenting a completely new approach to the taxonomy of plants and other organisms were published (e.g. Chase et al. 2000; Asmussen et al. 2006; Friesen et al. 2006; Lefébure et al. 2006). In many cases, the new classifications overturned those proposed earlier. Interestingly, one can note a disagreement between molecular based systems and morphological ones. Usually, priority was given to those based on the results of DNA fragment analyses, even though relatively often it was difficult or even impossible to interpret the topology of the tree in terms of its morphology. Yet, no systems based on limited datasets reflect the evolution of the whole organisms; rather, they focus just on the evolutionary modifications of the data in question. Using phylogenetic data to study speciation requires that potential limitations be kept in mind. The approach assumes that we have an accurate and complete understanding of the evolutionary relationships within a clade. Solid phylogenetic methods and markers are needed to reconstruct the phylogeny, which is often difficult, especially among recently diverged taxa.

The utility of nuclear gene sequences in intraspecific phylogenetic analyses appears to be limited by increased coalescence time as compared to chloroplast genes. In addition, the potential for reticulate evolution among nuclear alleles due to recombination is likely to further limit their utility for phylogenetic studies (Bermingham and Moritz 1998). When using organellar genes in combination with nuclear genes, several factors contribute towards an increase in the genetic structure encountered within plant species. For phylogenetic purposes, it would be desirable to consider multiple gene trees based on chloroplast and nuclear genomes, because independently derived gene trees may not be congruent (Schaal et al. 1998). However, Doyle (1997) notes that when the history of the organellar genome is different from that of the nuclear genome (e.g. in lineage sorting or introgression) every comparison sequence in these genomes will give a false phylogenetic pattern for those taxa, and this can confound phylogenetic reconstruction. Plant molecular phylogenetic studies at species levels are generally limited by the availability of sequences with levels of resolution suitable for the construction of well-supported trees (Doyle et al. 1996).

Defining Cyrtochilum s.l. Neubig et al. (2012) stated that "vegetatively Cyrtochilum are distinguished by dull pseudobulbs that are round or ovoid in cross section with two to four apical leaves and two to six leaf-bearing sheaths and relatively thick roots, in contrast Oncidium spp. have glossy, ancipitous (two-edged) pseudobulbs and thin roots". Unfortunately, characters mentioned by Neubig et al. (2012) do not warrant proper identification of Cyrtochilum, since the features selected by the authors as disciminative can be found also in other Oncidiinae, for example in Brassia s.l.

A problem has emerged as to how to explain the similarity between molecular marker sequences in morphologically different species, such as Cyrtochilum s.str. and "Cyrtochilum ramosissimum" or "C. angustatum", which 


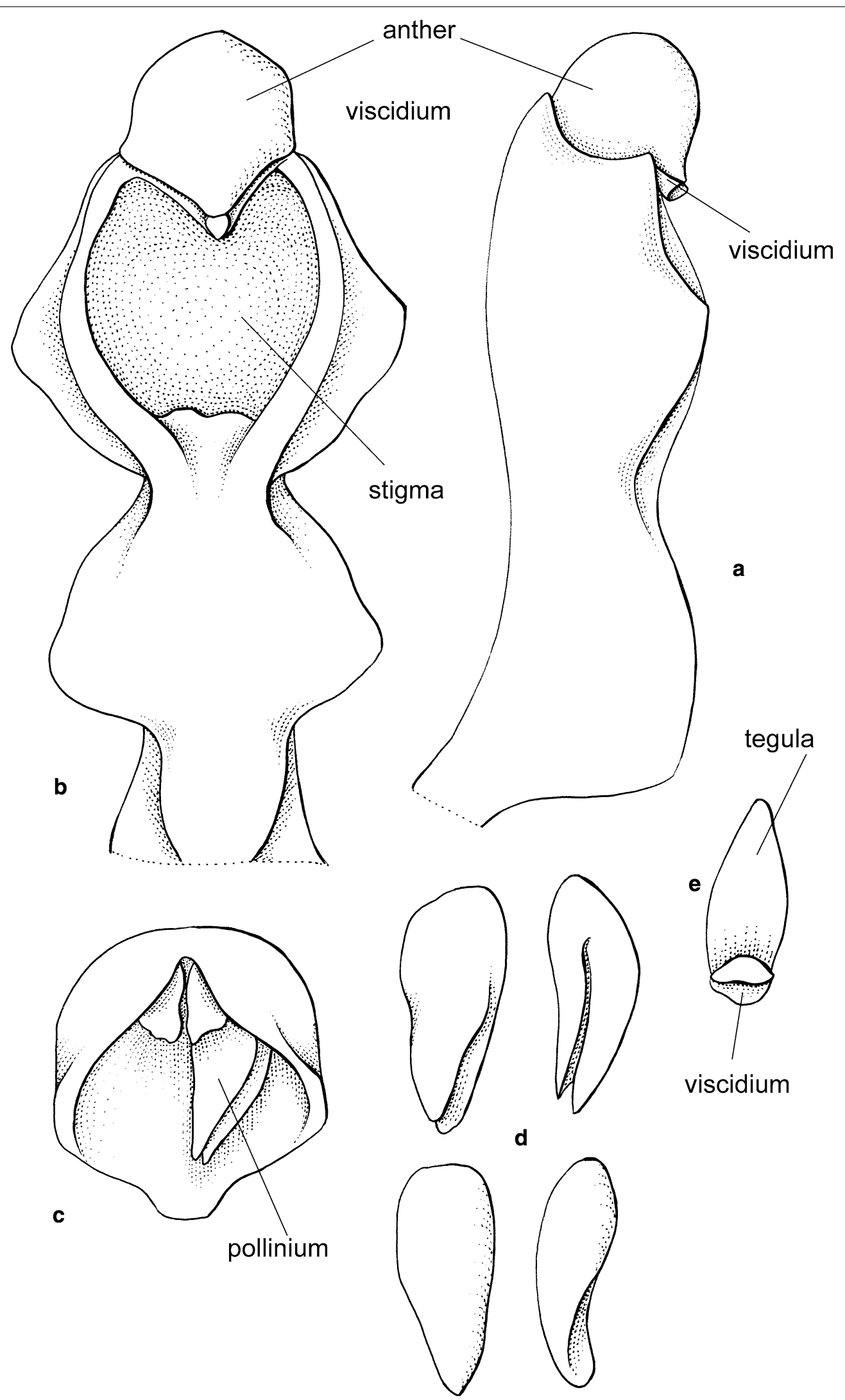

Fig. 12 Trigonochilum meirax. a Gynostemium, bottom view. b Gynostemium, side view. c Anther. d Pollinia, various views. e Tegula and viscidium (Szlachetko \& Mytnik-Ejsmont 2009) 


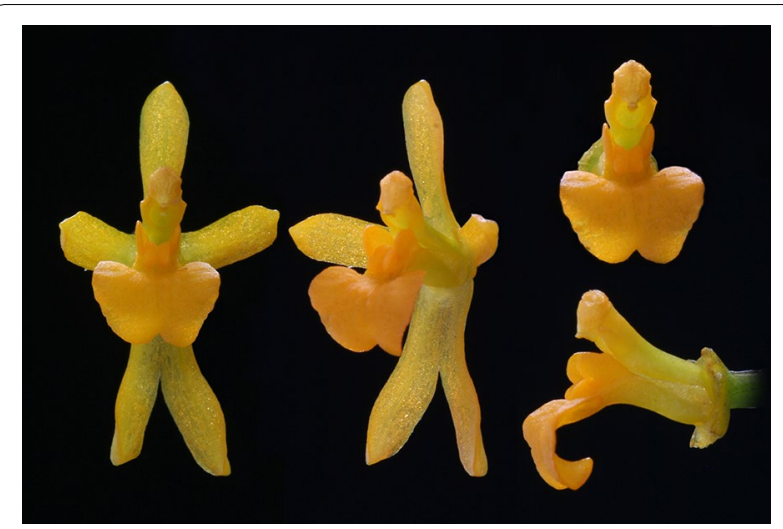

Fig. 13 Rusbyella aurantiaca. Photo: Guido Deburghgraeve

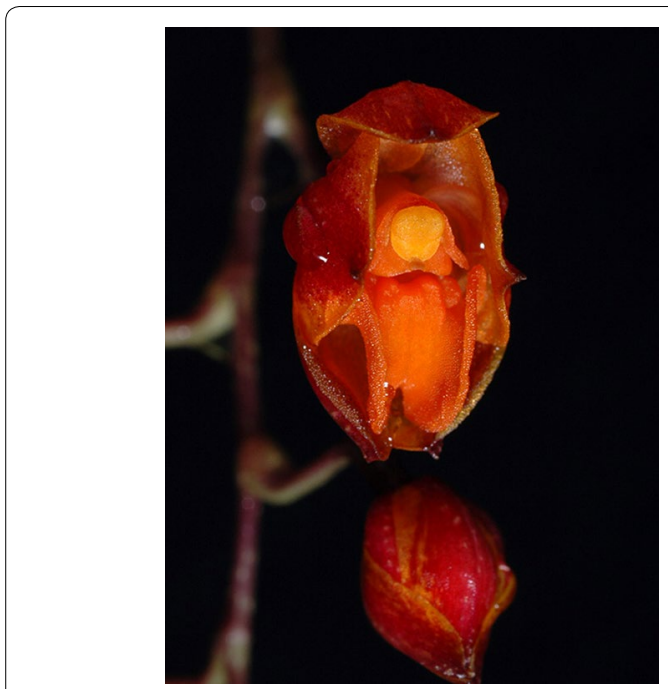

Fig. 14 Neodryas rhodoneura. Photo: Eric Hunt

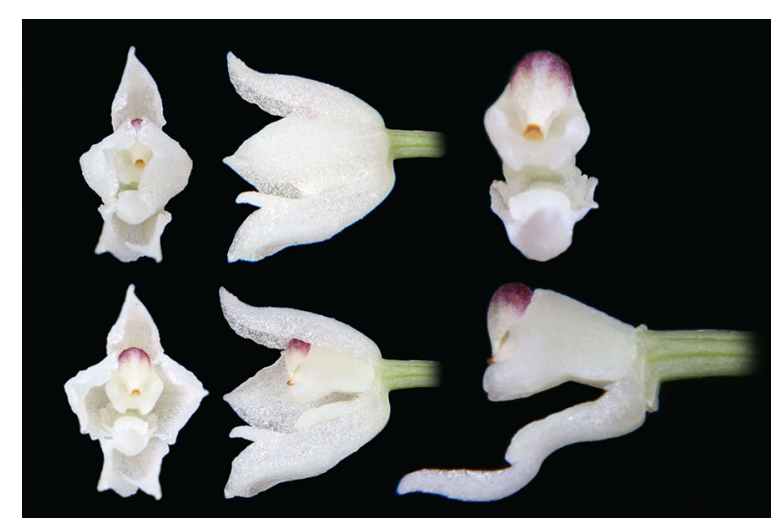

Fig. 15 Neodryas schildhaueri. Photo: Guido Deburghgraeve

together form a common phylogenetic branch. Neubig et al. (2012) stated that great variability in the flower architecture in Oncidiinae probably reflect a shift in pollinators. On the other hand, morphological similarity between phylogenetically distantly related taxa can be explained by homoplasy. It cannot be excluded, however, that the explanation is much more complicated.

There are at least some phenomena which can usher generate a disturbance to the topology of the phylogenetic tree. Ancestral hybridization, polyploidization and hybrid speciation are significant evolutionary forces in the Orchidaceae. Numerous examples of hybrids are noted in this group of plants. Interspecific hybrids occur in Orchidaceae, but they are typically sporadic and local (e.g. Cozzolino and Aceto 1994; Cozzolino et al. 1998). On the other hand, some putative orchid hybrids are more widespread and stabilized (e.g. Hedrén 1996, 2001; Arft and Ranker 1998; Bullini et al. 2001). Most polyploid species have formed recurrently from genetically-distinct diploid progenitors, representing a potentially great gene pool for the derivative polyploid. Relatively recent hybrid-derived species disclose some degree of morphological intermediacy between putative parents or a similarity to one of the parents. Furthermore, such deviation from intermediacy may be expected in a stablilized hybrid that has been under various selective pressures (Goldman et al. 2004).

A genomic investigation has demonstrated that polyploidization and hybridization are highly effective evolutionary mechanisms for introducing new plant species, promoting their persistence, and ultimately increasing the diversity of plant species (Cook et al. 1998; Ramsey and Schemske 1998; Soltis and Soltis 1999; Otto and Witton 2000; Wendel 2000; Hewitt 2001). While hybridization can be a threat to species integrity, it can also be a source of new variation and a source of new species, especially through polyploidy (Grant 1981).

The stability of the polyploid genome depends on nonrandom genetic changes, including chromosome and genome gains and losses of loci. This genomic reorganization seems to proceed quickly (Rieseberg et al. 1996; Rieseberg 1997; Buerkle and Rieseberg 2008), for example, after 10-60 generations in the case of Helianthus anomalus (Ungerer et al. 1998).

Hybrid speciation appears to be facilitated by several additional factors, for example, availability of a suitable ecological niche or development of appropriate fitness (Rieseberg 1997; Mallet 2007). To be evolutionarily successful, even fertile and stable hybrids must be reproductively isolated from the parental species either by chromosomal sterility factors, or evolution of reproductive barriers, or divergence into a new ecological niche (Grant 1981; Rieseberg 1997, 2001; Wu 2001; Paun et al. 2009).

In the case of species of hybrid origin, we expect the conflict of the topology between nuclear and plastid genes. Below we explain the mechanisms leading to 


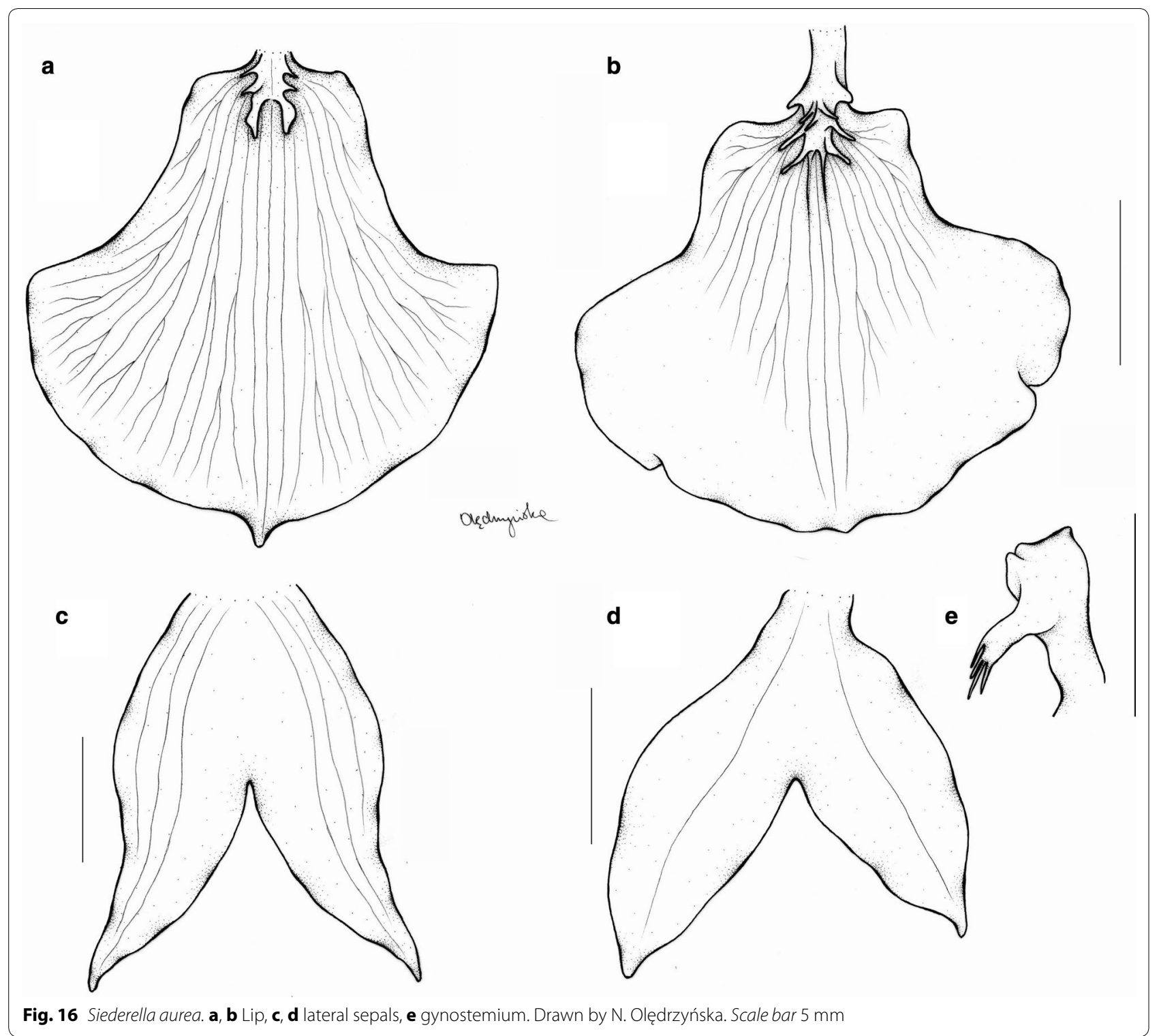

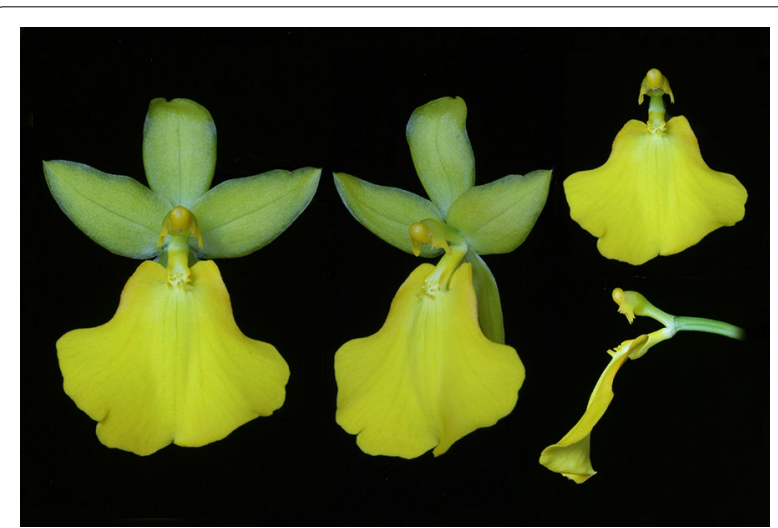

Fig. 17 Siederella aurea. Photo: Guido Deburghgraeve these conflicts. Consider a situation of conflict between molecular and morphological data. There are two possibilities of such cases. The first concerns the situation where two related taxa differ morphologically due to the divergent evolution resulting as adaptation to different habitats and/or pollinators. The second case explains this phenomenon by referring to the convergence that results from adaptation to a common pollinators. But there is a third solution to the conflict-reticulate evolution. To make its detection should be compared to a tree topologies based on plastid and nuclear sequences. The phylogenetic analyses conducted by Neubig et al. (2012) used a nuclear marker: ITS1-5.8S-ITS2, which is part of a family of genes coding for ribosomal DNA (rDNA). 

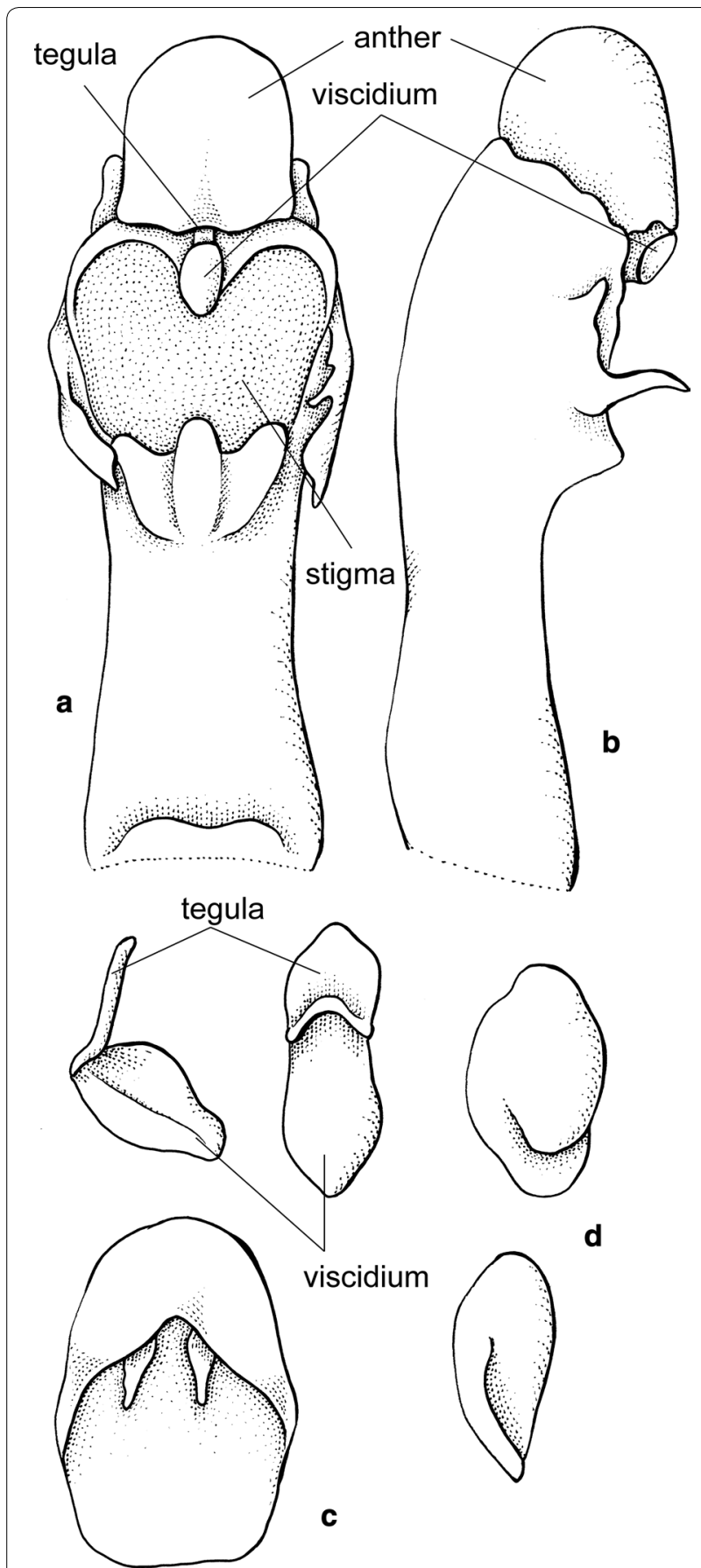

Fig. 18 Siederella aurea. a Gynostemium, bottom view. b Gynostemium, side view. c Anther. d Pollinia, various views (Szlachetko \& Mytnik-Ejsmont 2009)

In higher plant rDNA is organized into arrays at one or more chromosomal locations (Rogers and Bendich 1987; Hillis and Dixon 1991). Each array contains hundreds to thousands of identical to near-identical repeats. The repeats having become homogenized by evolutionary forces like unequal crossing-over (Seperack et al. 1988) or gene conversion (Enea and Corredor 1991; Hillis et al. 1991) that are referred to as concerted evolution (Zimmer et al. 1980; Arnheim et al. 1980). Wendel et al. (1995) observed complete or nearly complete interlocus concerted evolution of the ITS region in diploid and polyploidy Gossypium species. Moreover, they observed this phenomenon in other components of rDNA repeat. These authors also observed, that concerted evolution has occurred bidirectionally in analysed species. One of the five polyploid hybrids (Gossypium mustelinum) had rDNA repeat from female parent (receiver of the pollen) and remaining polyploids (G. tomentosum, G. hirsutum, G. darwini, G. raimondii) has become homogenized to a male parent (donor of the pollen) rDNA repeat. In such case, ITS sequences from the allopolyploid species occur on both branches of phylogenetic tree, each close to the one of the parental species. In case of maternally inherited plastid DNA, which occurs in most angiosperms, both rDNA lineage has the same plastid DNA lineage. So we can detect species of hybrid origin only with one of this case. The use of nuclear ITS sequences in phylogenetic analyses for the species of hybrid origin may lead to an underestimation of the phylogeny. Due to the frequent occurrence of hybridization in plants, especially in orchids seems to be a reasonable use of the other nuclear markers in order to properly assess the phylogenetic relationship between the analysed taxa. Low-copy nuclear genes, which are less liable to concerted evolution, can potentially serve as a very useful marker for reconstructing allopolyploidization (Small et al. 1998).

There is another question about the potential hybridization between the Cyrtochilum and Odontoglossum species. Orchids are especially prone to hybridization, partly due to the frequent weakness or even absence of postzygotic barriers to gene exchange. Instead, many orchids rely heavily on pre-zygotic barriers, notably pollinator preference (e.g. Tremblay et al. 2005; Schiestl and Cozzolino 2008). Orchids, in general, are adapted to various forms of zoogamy and their flowers are accommodated to pollination by various factors, which is one of the reasons for the high degree of variability in the flower, androecium and gynoecium structures. Unfortunately, there are only a few reports concerning this phenomenon in Cyrtochilum and Odontoglossum. Van der Pijl and Dodson (1966) noted Bombus hortulanum and Centris bees pollinating Cyrtochilum macranthum. Van der Cingel (2001) assumed that the bright-flowered, high-elevation " $C$. retusum" might be hummingbird-pollinated. The flowers of Odontoglossum s.str. have also been observed to be pollinated by Bombus hortulanum (van der Pijl and Dodson 1966) trying to find reward in the cavity formed by the basal part of the lip and gynostemium. The presence 


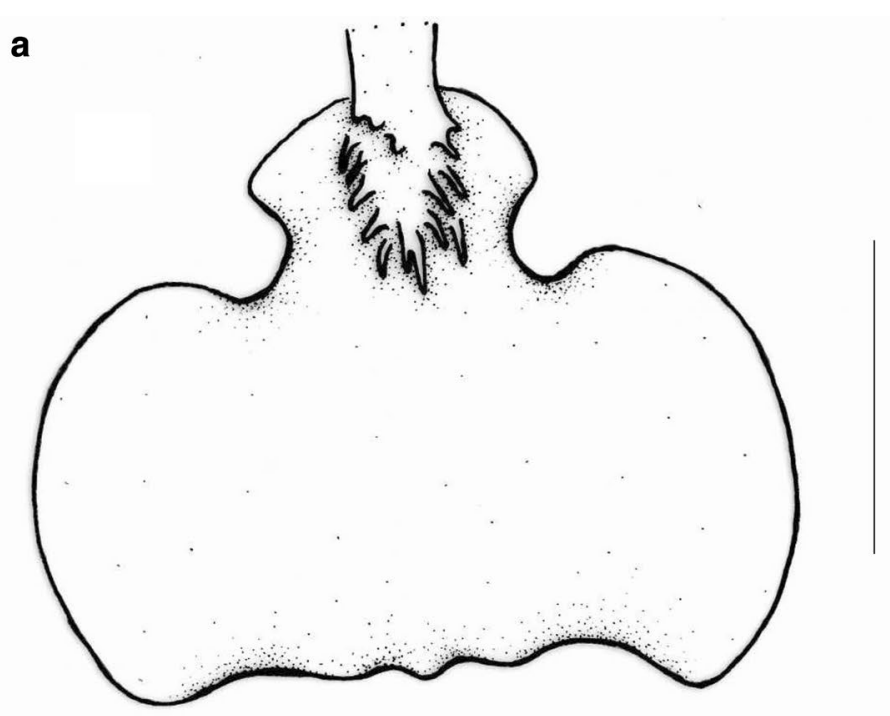

b
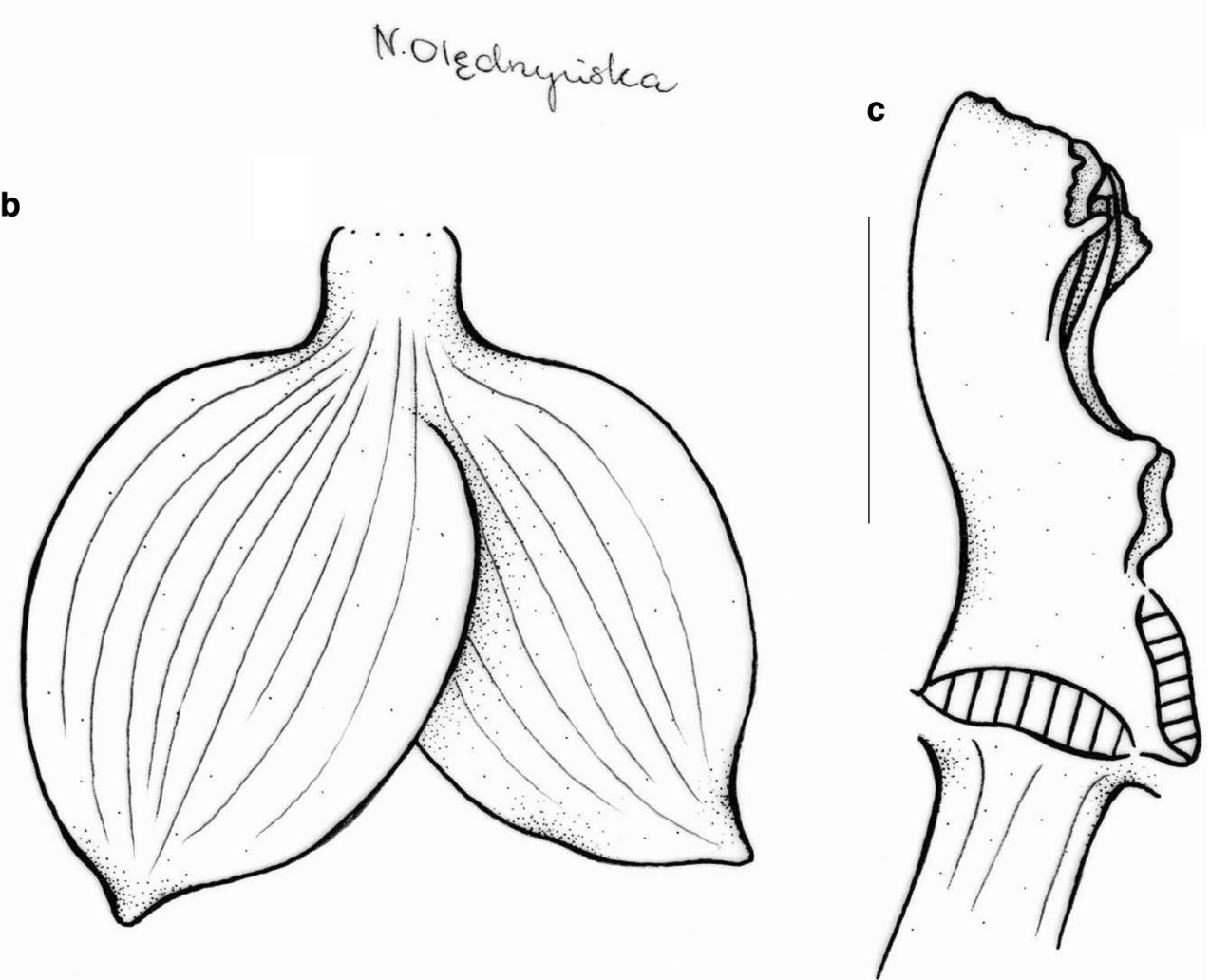

Fig. 19 Oncidium loxense. a Lip, b lateral sepals, c lip. Drawn by N. Olędrzyńska. Scale bar $\mathbf{a}, \mathbf{b}=10 \mathrm{~mm}, \mathbf{c}=5 \mathrm{~mm}$

of a hairy lip in some Odontoglossum species might suggest pollination conducted by certain callus-collecting insects. In other words, there is a distinct possibility that the species of both Cyrtochilum and Odontoglossum coul share the same or similar pollination agents, which enable gene flow between plants representing different genera. We have assumed that Odontoglossum-like
Cyrtochilum, i.a. "C. angustatum", " $C$. pardinum", " $C$. ramosissimum", could be of hybrid origin or, at least, demonstrate a stronger influence of genetic materials from Odontoglossum. It is noteworthy that in 2004 Shaw registered an artificial hybrid between Odontoglossum and Cyrtochilum named $\times$ Cyrtoglossum (Fig. 21). The hybrid is characterized by clawed tepals (with petals 


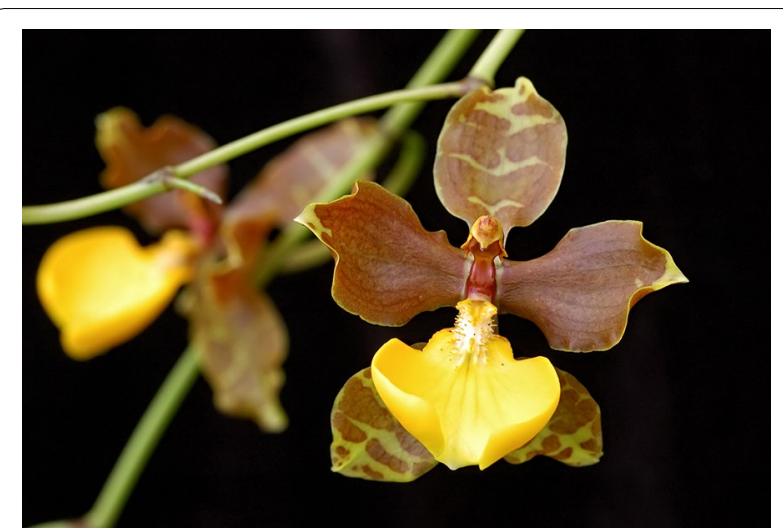

Fig. 20 Oncidium loxense. Photo: Eric Hunt

claws short and wide), and slightly sigmoid gynostemium with winged projections on both sides of stigma. Interestingly, the form of the lip, i.e. oblong obtriangular, with exposed callus reminds Cyrtochilum macranthos.

The evolution of sister species is not always combined with parallel evolutionary shifts in pollination syndromes (Cozzolino and Widmer 2005). As a consequence, these closely related species, usually growing in sympatry and having overlapping flowering periods and non-specific pollination are exposed to ample opportunities for interspecific hybridization (van der Cingel 2001; Jersáková et al. 2006).

It is worthy to mention that the paper published by Stegemann et al. (2012) concerning horizontal gene transfer (HGT), which sheds new light on an incongruity between molecular datasets of various origin. The authors discovered that chloroplast genomes can be readily transferred between relatively closely related species by natural grafting, thus also providing a possible explanation for why chloroplast sequences frequently provide trees that disagree with canonical phylogeny and/or trees constructed with nuclear markers.

It is also possible that portions of genomes can be transferred between even very distantly related lineages via, for example, viral vectors (Won and Renner 2003; Bergthorsson et al. 2004). This process was noticed as a possible cause of erroneous tree topologies by Tyteca and Klein (2008). On the other hand, Tsai et al. (2010) obtained heterogeneous plastid DNA within individuals of two Phalaenopsis species-P. lowii and P. gibbosa. The short DNA fragments in both the trnL intron and the $a t p \mathrm{~B}-r b c \mathrm{~L}$ intergenic spacer also had indels based on the sequence alignment. One explanation for the different copies of plastid DNA within an individual is the fact that the short form of the plastid DNA might be maintained in the nuclear or mitochondrial genome through horizontal gene transfer (Ellis 1982; Cheung and Scott 1989; Ayliffe and Timmis 1992; Ayliffe et al. 1998). Horizontal transfer can occur in large fragments coming from the organellar genome into the nuclear genome (Yuan et al. 2002; Huang et al. 2005).

Taking into consideration the aforementioned reports, both HGT as well as hybridization might be responsible

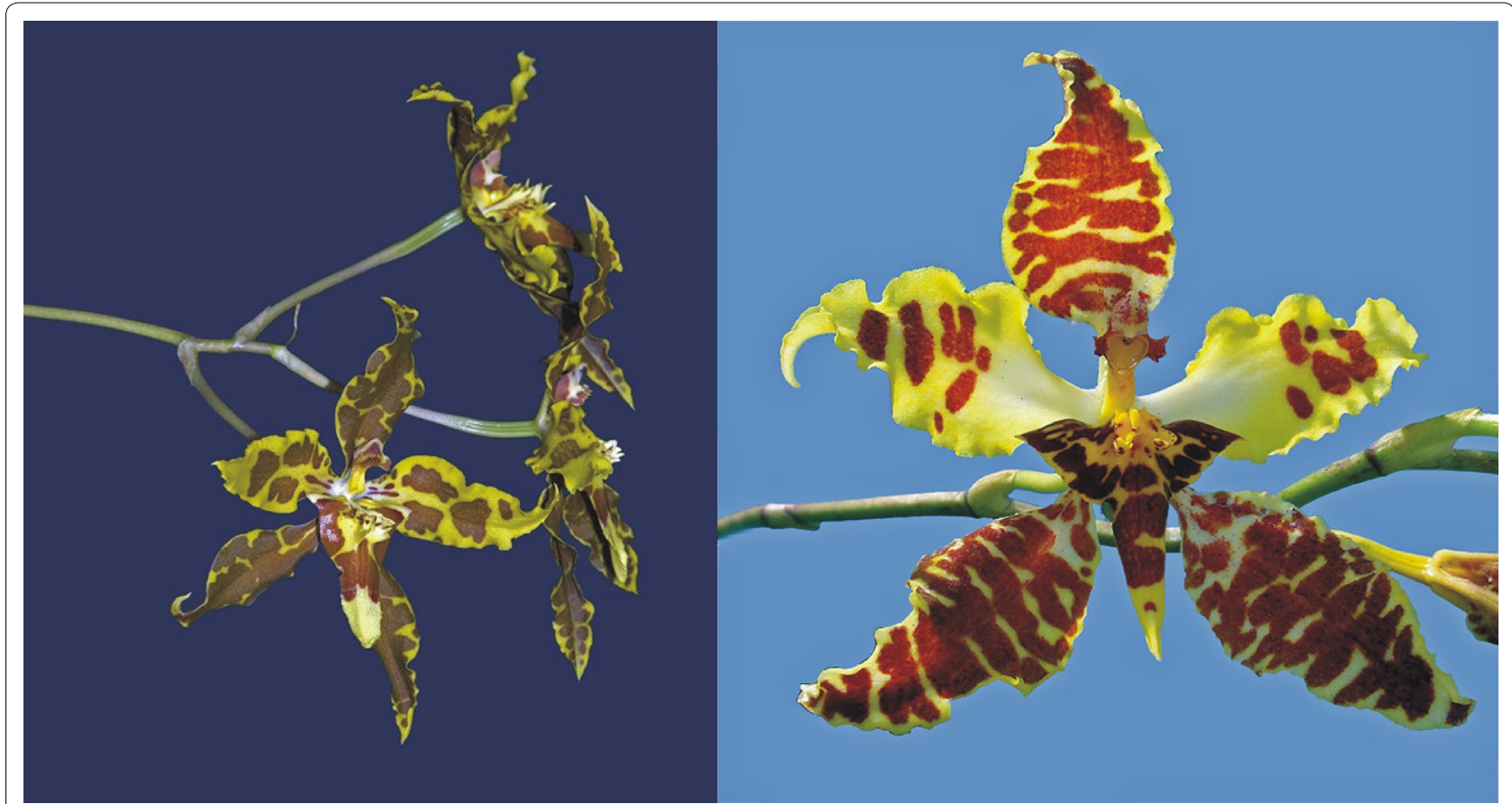

Fig. 21 Cyrtoglossum flowers. Photos provided by Ecuagenera 
for the topology of phylogenetic trees and the puzzling position of some species. Reconstruction of evolutionary history in genera strongly affected by reticulation and polyploidization is definitely not an easy task. Importantly, Cyrtochilum and Odontoglossum species inhabit similar geographical regions and plant communities, i.e. Andean humid montane and premontane forests, often growing together, which facilitates gene/genome transfer. The Andes are a well-known centre of biodiversity, where the process of speciation can take place freely as a result of various geographic conditions (cf. Bates et al. 2008; Richter et al. 2009), and ecological factors. Of course, it could be one of many other explanations for the observed topology of the Cyrtochilum phylogenetic tree.

Intraspecific gene evolution cannot always be represented by a bifurcating tree model. Linder and Rieseberg (2004) and Vriesendorp and Bakker (2005) have pointed to the fact that the evolutionary history of many plant groups does not follow divergent evolutionary patterns, and hardly can be unravelled in a tree-building procedure. Rather, it is like a network, which displays a number of reticulate evolutionary events. The family Orchidaceae is not an exception, and poliploidy and hybridization are events, which often result in a reticulated pattern of evolution.

The incompatibility of gene trees does not necessarily constitute evidence for reticulate evolution, as gene phylogenies may conflict with other processes: the gene trees may not be historically accurate due to model misspecification or inappropriate methodology, or due to sampling effects (i.e. insufficient sites to compensate for site saturation or short interior edges); alternatively, the gene phylogenies may be historically correct but differ from the species tree due to the population-genetic effect known as lineage sorting (Maddison 1997; Sang and Zhong 2000; Rosenberg 2002).

To most taxonomists, classification depends on characteristics and we have assumed that to cladists the features are no longer important. A classification should be able to recognize distinctive characteristics which have evolved in a group and if we cannot do that it is in consequence impossible to reflect evolution (Brummitt 2006). Brummitt's point of view is shared by many other authors (see 150 scientists who signed a letter by Nordal and Stedje 2005), who state that the traditional classification is the optimal tool for cataloguing biodiversity and requires the recognition of paraphyletic taxa.

The dilemma with which every taxonomist has to struggle is fragmentation or lumping of taxonomic units. Both of them can generate various problems. The effect of the fragmentation of taxa is the creation of numerous smaller, but morphologically well-defined genera, whereas integration produces fewer taxa, well-established genetically, but poorly circumscribed morphologically. The borders between taxonomic units are rather a matter of taxonomic philosophy than scientific objectivity. In our opinion, reasonable fragmentation of taxa can be accepted as long as it leads to separation of well-defined entities. We deal with the latter situation in the case of Cyrtochilum s.l. We hypothesise that groups of species forming the particular subclades presented above make well-matched genera which evolve in various directions in response to pollinator pressure, which is manifested, e.g. in various spans between lip and gynostemium and the type of the lip calli.

Interestingly, molecular taxonomists attempt to appoint their taxa using morphological characteristics. Unfortunately, they often create ill-defined units and Cyrtochilum sensu latissimo is an example. Until more data become available concerning the influence of horizontal gene transfer, as well as hybridization and polyploidy on speciation in the Cyrtochilum alliance, thus enabling the solution of the problem of incongruity between molecular and morphological datasets, we suggest maintaining a narrower generic concept.

As stated at the beginning of this chapter, Neubig et al. (2012) definition of Cyrtochilum does not warrant the proper identification of the genus representatives and can lead to the confusion. We propose to recognize at the generic level smaller, monophyletic and morphologically well-defined taxa, what in our opinion assure stability in taxonomy of this interesting oncidoid group.

\section{Taxonomic treatment}

Key to the genera of Cyrtochilum-complex

1. Gynostemium and the lower part of the lip form more or less a right angle ... 2

1 . Gynostemium parallel with the lower part of the lip ... 4

2. Lip unguiculate, lamina more or less transversely elliptic, callus rather obscure, lateral sepals basally connate ... Siederella

$2^{*}$. Lip sessile to subsessile, lamina cordate, sagittate to hastate, callus prominent, lateral sepals free to the base or almost to the base ... 3

3. Lip much smaller than tepals, callus very large, complexed, composed of horns and various digitate projections ... Cyrtochilum

$3^{*}$. Lip as large as tepals, triangular-cordate in outline, callus large, composed of large mass of tissue divided into 4 or more lobes ... Trigonochilum

4. Lip callus simple, consisting of 2 fleshy, parallel, adjoining torus, diverging in front ... Dasyglossum $4 *$ Lip callus not as above ... 5 
5. Gynostemium with digitate projections on each sides of the stigma, lip sessile, callus prominent ... Neodryas

$5^{*}$. Gynostemium with or without very obscure projections, lip long clawed, callus obscure ... Rusbyella Cyrtochilum Kunth

Nov. Gen. Sp. 1: 279. 1816; Generitype: Cyrtochilum undulatum Kunth.

Epiphytic or terrestrial plants. Pseudobulbs ovoid, usually round in cross-section, distributed on elongate creeping rhizome, sometimes caespitose, but clusters of pseudobulbs usually distantly remote along the rhizome, with 2-6 foliaceous bracts. Leaves 2-4 per pseudobulb, conduplicate, articulate. Inflorescence flexuose, usually very long, branched, branches with few to many flowers. Flowers resupinate, showy, white, yellow, pink, brown or purple. Floral bracts large, leafy. Tepals free, prominently unguiculate, similar in size and shape or petals much wider. Lip triangular to ovate rarely hastate to panduriform, apex reflexed, callus complex, often digitate, tuberculate or horned. Gynostemium gently sigmoid to erect, elongated, slender, clavate, usually forms right angles with lip. Anther subventral, incumbent, operculate, ellipsoid-ovoid. Pollinia 2, oblong ellipsoid, hard, unequally and deeply cleft, empty inside. Stigma large, elliptic, deeply concave. Rostellum short. Viscidium single, relatively large, elliptic, very thick, concave in the centre of the outer surface. Tegula single, very small, transversely elliptic-obtriangular, obscurely bilobulate at the apex, thin, lamellate. Rostellum remnant with oblique shallowly concave plate at the apex, canaliculate on the upper surface (Fig. 1). Capsule triangular.

Taxonomic notes-Species of the genus Cyrtochilum, as treated here, are easily distinguishable from all other genera of the clade by having elongated, flexuose inflorescence, large, showy flowers with clawed, large sepals and petals, a relatively small lip widest at the base, attenuated towards apex, with a composed callus occupying a large portion of the lip lamina, and gynostemium gently sigmoid to erect, slender, usually perpendicular to the lip base, or even deflexed. We assume that a group of $C$. angustatum-group can be of hybrid origin.

Dasyglossum Königer \& Schildh.

Arcula 1: 5 1994; Generitype: Dasyglossum myanthum (Lindl.) Königer \& Schildh. [三Odontoglossum myanthum Lindl.].

Epiphytic plants. Pseudobulbs approximate, ovoid or elliptic-oblong, compressed, enveloped at the base by papery or foliaceous sheaths. 1-3 leaves, coriaceous or fleshy. Inflorescence usually elongated, erect or arching, few to many flowers, racemose or paniculate. Flowers small. Floral bracts rudimentary. Sepals free, occasionally basally connate, subequal, spreading. Petals usually subequal to the dorsal sepal. Lip entire or 3-lobed, at the base united with the base of the column, lower half of the lip parallel to the column; callus simple, often consisting of 2 fleshy, parallel, adjoining tori, diverging in front, mostly enclosed by the thickened flanks of the gynostemium. Gynostemium rather short, in the upper half gently upcurved or straight, rather robust. Column part ca. 2.5 times longer than anther, fused with the lip in the basal half, firmly winged, wings entire on margins, surrounding lip callus. Anther subdorsal to apical, operculate, ellipsoid, obscurely 2-chambered. Pollinia 2, oblong ellipsoid-ovoid, hard, unequally and deeply cleft. Stigma oblong to transversely elliptic, slightly concave. Rostellum suberect to pendent, rather short, ovate, rounded at the apex. Viscidium single, oblong ellipsoid, very thick, fleshy. Tegula single, as long as viscidium, oblong, thin, lamellate, flat. Rostellum remnant bilobulate at the apex (Fig. 10).

Taxonomic notes-All representatives of the genus are easily separable from other taxa of the Cyrtochilum alliance by the presence of a short, massive gynostemium, winged on the ventral surface, and parallel with the lower part of the lip.

The following new combinations are validated below:

Dasyglossum colobium (Dalström) Szlach., Kolan. \& Chiron, comb. nov.

Basionym: Cyrtochilum colobium Dalström in Dodson \& Luer, Fl. Ecuador, Orchidaceae 87: 51. 2010. Type: Ecuador. Sucumbíos, cloud forest W of La Bonita. 29 Mar 1992. Dalström \& Höijer 1687 (Holotype: SEL).

Dasyglossum ferrugineum (Dalström \& D. Trujillo) Szlach., Kolan. Chiron, comb. nov.

Basionym: Cyrtochilum ferrugineum Dalström \& D. Trujillo in Dodson \& Luer, Fl. Ecuador, Orchidaceae 87: 74. 2010. Type: Ecuador. Sine loc. hort. Beckendorf sub Dalström 2377 (Holotype: SEL).

Dasyglossum fidicularium (Dalström) Szlach., Kolan. \& Chiron, comb. nov.

Basionym: Odontoglossum fidicularium Dalström, Lindleyana 14(3): 168. 1999. Type: Ecuador. ZamoraChinchipe. Along road between Yanga and Valladolid. 21 Feb 1982. Luer et al. 7134 (Holotype: SEL, Isotype: K).

Dasyglossum hoeijeri (Dalström) Szlach., Kolan. \& Chiron, comb. nov.

Basionym: Odontoglossum hoeijeri Dalström, Lindleyana 14(3): 171. 1999. Type: Ecuador. Loja. North of Loja, along road to Saraguro. 8 Feb 1993. Dalström et al. 1871 (Holotype: SEL, Isotype: K). 
Dasyglossum sphinx (Dalström \& G.Calat.) Szlach., Kolan. \& Chiron, comb. nov.

Basionym Cyrtochilum sphinx Dalström \& G.Calat., in Dodson \& Luer, Fl. Ecuador, Orchidaceae 87: 170. 2010. Type: Peru. Cajamarca. Prov. San Ignacio, San José de Lourdes. Calatayud 746 (Holotype: CUZ).

Dasyglossum verrucosum (Dalström) Szlach., Kolan. \& Chiron, comb. nov.

Basionym: Cyrtochilum verrucosum Dalström in Fl. Ecuador 87: 183. 2010. Type: Ecuador. Morona-Santiago. Ecuagenera sub Whitten 3219 (Holotype: QCA). Neodryas Rchb.f.

Bot. Zeit. 10: 835. 1852; Generitype: Neodryas rhodoneura Rchb.f.

Buesiella C.Schweinf., Bot. Mus. Leafl., Harvard Univ. 15: 153. 1952; Generitype: Buesiella pusilla C.Schweinf.

Plants caespitose. Pseudobulbs cylindrical-ovoid, enclothed basally with 1-3 leafy sheaths, unifoliate. Inflorescence more or less branching, branches with few to many flowers. Flowers medium-sized, campanulate, somewhat laterally compressed. Sepals narrower than petals, both sessile. Lateral sepals variously connate. Lip sessile, entire, oblong-ovate to ligulate-subcordate, geniculate near the middle, callus large, variously lobed. Gynostemium almost erect, stout, parallel to the lip. Column part ca. twice longer than anther, widened in the middle, wings spread, oblong-elliptic, with digitate projections on each side of the stigma. Pollinia 2, obliquely obovoid-ellipsoid, slightly dorsiventrally compressed, hard, unequally and shallowly cleft at the apex. Apical clinandrium forms a narrow collar surrounding the anther base. Stigma rather large, transversely elliptic, deeply concave. Rostellum suberect, short, ligulate. Viscidium single, small, elliptic-ovate, thin. Tegula single, oblongelliptic, thin, lamellate. Rostellum remnant bilobulate at the middle, slightly concave between acute lobules, canaliculate on the dorsal surface.

Taxonomic notes-We did not identify any morphologically crucial differences between Neodryas and Buesiella. Therefore, we have combined them together which is also supported by the results of the analyses of the DNA markers. The genus is characterised by the presence of a gynostemium parallel with a sessile lip furnished with a large callus.

Neodryas fredericae (Dalström) Szlach., Kolan. \& Chiron, comb. nov.

Basionym Cyrtochilum fredericae Dalström, in Dodson \& Luer, Fl. Ecuador, Orchidaceae 87: 86. 2010. Type: Ecuador. Loja. Cajanuma. Ecuagenera sub Dalström 2478 (Holotype: SEL).

Rusbyella Rolfe ex Rusby
Mem. Torrey Bot. Club 6: 122. 1896; Generitype: Rusbyella caespitosa Rolfe ex Rusby.

Plants caespitose. Pseudobulbs oblong to cylindricalovoid, slightly laterally compressed, enclothed basally with 1-2 leafy bracts, unifoliate. Inflorescence erect, simple or branching. Flowers medium-sized. Sepals and petals subsimilar, narrow. Lateral sepals variously connate. Lip clawed, claw narrow, channelled, furnished at the apex with quadrilobed callus, lamina transversely elliptic to reniform, abruptly reflexed. Gynostemium elongated, slightly swollen and bent back at the apex, parallel with the lower part of the lip. Column part ca. 1.5 times longer than anther, glabrous, with two wing-like projections on both sides of the stigma. Anther subdorsal, incumbent, operculate, dorsiventrally compressed, obovoid-ellipsoid. Connective narrow, thin, forming prominent, apical, rooflike projection in front. Pollinia 2, obliquely obovoid, shallowly cleft at the apex, hard. Apical clinandrium forms a narrow collar-like structure surrounding the anther base. Stigma rather small, oblong elliptic, concave. Rostellum suberect, ligulate, rounded at the apex. Viscidium very small, single, elliptic, thin. Tegula single, linear, thin, lamellate. Rostellum remnant with oblique, apical plate on the inner surface surrounded by obscure fovea.

Taxonomic notes-Rusbyella is easily separable from other genera of the Cyrtochilum alliance by having a lip with a long, channelled claw, and parallel gynostemium with an apical part and anther bent back.

\section{Siederella Szlach., Mytnik, Górniak \& Romowicz}

Biodiv. Res. Cons. 1-2: 5. 2006; Generitype: Siederella aurea (Lindl.) Szlach., Mytnik, Górniak \& Romowicz [三Oncidium aureum Lindl.]

Plants caespitose. Pseudobulbs ovoid, somewhat laterally compressed, enclothed basally in some leafy sheaths, usually unifoliate. Inflorescence erect, loosely severalflowered. Flowers rather large, showy; sepals and petals subsimilar, sessile. Lateral sepals connate almost to the apex. Lip shortly unguiculate, callus variously developed-almost missing or two parallel ridges, lamina obovate to pandurate. Gynostemium slightly arched, elongated, slender, forming a $30^{\circ}$ angle with the lip. Column part ca. 3 times longer than anther, basally joined with the lip, with two projections near the stigma, more or less finger-like. Anther subventral, incumbent, operculate, ellipsoid-obovoid, obscurely 2-chambered. Connective narrow, indistinctly apically elongate. Pollinia 2, obliquely ellipsoid, hard, unequally and deeply cleft, empty inside. Caudiculae sticky, amorphous. Apical clinandrium forms a narrow collar-like structure around the anther base. Stigma large, elliptic, deeply concave. 
Rostellum shortly conical-digitate in the middle, ligulate, blunt. Viscidium single, rather large, oblong elliptic, very thick. Tegula single, small, linear, thin, and lamellate (Fig. 18).

Taxonomic notes-This genus differs from Rusbyella in terms of gynostemium and lip morphology. The lip claw possesses two, parallel elevated calli. The gynostemium forms an acute angle with the lip, it is terete below the stigma, and with small, finger-like projections near the stigma.

\section{Incertae sedis}

Oncidium loxense Lindl. is similar to Cyrtochilum Kunth with which it shares a similar habit, creeping rhizome, long, flexuose, branching inflorescence, large flowers, clawed sepals and petals and gynostemium forming a right angle with the lip. Differs from most species of the genus by having connate lateral sepals, a large, prominently unguiculate lip, with an obscure callus, transversely elliptic or obreniform, concave lip lamina. The lip is somewhat similar to C. volubile (Fig. 22) and $C$. villenaorum, but despite these species it is prominently clawed and callus is obscure. Temporarily, we propose to maintain this species in Siederella.

Siederella loxense (Lindl.) Szlach., Kolan. \& Chiron, comb. nov.

Basionym: Oncidium loxense Lindl., Paxt. Fl. Gard. 2: 128. 1851. Type (Dalström 2010): Ecuador. Hartweg s.n. (Lectotype: K-L, Isolectotype: W).

Trigonochilum Königer \& Schildh.

Arcula 1: 13. 1994; Generitype: Trigonochilum flexuo$\operatorname{sum}$ (H.B.K.) Königer \& Schildh. [三Cyrtochilum flexuosum H.B.K.].

Epiphytic plants. Pseudobulbs approximate, ovoid or elliptic-oblong, compressed, enveloped at the base by papery or foliaceous sheaths. 1-3 leaves, coriaceous or fleshy. Inflorescence from the base of pseudobulb, usually very long, twining, frequently with short, zigzag branches. Flowers relatively small. Floral bracts small. Sepals free, subequal, spreading. Petals usually subequal to the dorsal sepal. Lip triangular-cordate in outline, diverging from the gynostemium at $70^{\circ}-90^{\circ}$ with a simple, torous, sometimes verrucose or gibbous callus. Gynostemium elongate, slightly sigmoid to erect, rather slender. Column part 2-4 times longer than anther, with deltoid tabula infrastigmatica, obscurely winged near the stigma, glabrous, wings triangular, entire on margins. Anther subventral, incumbent, operculate, ellipsoidovoid, obscurely 2-chambered. Pollinia 2 , oblong obovoid, slightly dorsiventrally flattened, hard, unequally and deeply cleft. Stigma elliptic, deeply concave. Rostellum short, conical-digitate in the middle, blunt. Viscidium single, very small, elliptic, rather thick. Tegula single, oblong ovate, thin, lamellate, with roof-like projection above viscidium. Rostellum remnant bilobulate at the middle (Fig. 12).

Taxonomic notes-Considering the flower structure, the genus appears to be similar to Cyrtochilum. In both taxa, the gynostemium is more or less perpendicular to the lip base, but unlike Cyrtochilum, in Trigonochilum the petals and sepals are sessile and the lip is wider than the tepals, lip lamina is triangular-cordate in outline in major part occupied by a massive callus.

Our course of study on the North Andean orchids revealed the existence of an undescribed Trigonochilum species from the Colombian Department of Putumayo, as well as the necessity of including into the genus Peruvian, Ecuadorian and Colombian species of Cyrtochilum.

Trigonochilum corniculatum (Dalström) Szlach., Kolan. \& Chiron, comb. nov.

Basionym: Cyrtochilum corniculatum Dalström in Dalström \& Perez, Lankesteriana 12(3): 147. 2012. Type: Colombia. Antioquia. Yarumal, Km 87 along road Medellín-Yarumal, Llanos de Cuiba [Cuiva]. 12 Sep 1984. Dodson et al. 15264 (Holotype: RPSC, Isotype: MO).

Trigonochilum midas (Dalström) Szlach., Kolan. \& Chiron, comb. nov.

Basionym: Cyrtochilum midas Dalström, in Dodson \& Luer, Fl. Ecuador, Orchidaceae 87: 136. 2010. Type: Ecuador. Morona-Santiago. Macas-Guamote. Jan 1989. Hirtz et al. 4061 (Holotype: RPSC).

Note: Orchid collection of RPSC was transferred to MO. Trigonochilum russellianum (Dalström \& RuízPérez) Szlach., Kolan. \& Chiron, comb. nov.

Basionym: Cyrtochilum russellianum Dalström \& Ruíz-Pérez, Lankesteriana 12(3): 149. 2012. Type: Peru. Ayacucho. La Mar, Aina, Calicanto. Peruflora sub Dalström 3415 (Holotype: USM).

Trigonochilum sharoniae (Dalström) Szlach., Kolan. \& Chiron, comb. nov.

Basionym: Cyrtochilum sharoniae Dalström, Selbyana 28(2): 106. 2007. Type: Peru. Sine loc. Peruflora sub Daltröm 2638 (Holotype: SEL).

Trigonochilum tanii (Dalström) Szlach., Kolan. \& Chiron, comb. nov.

Basionym: Cyrtochilum tanii Dalström in Dodson \& Luer, Fl. Ecuador, Orchidaceae 87: 172. 2010. Type: Ecuador. Manabí, $11 \mathrm{~km}$ east of Manta, summit of Cerro Monte Cristi. Cult. SEL sub Tan 1361 (Holotype: SEL).

Trigonochilum tricornis (Dalström \& Ruíz-Pérez) Szlach., Kolan. \& Chiron, comb. nov. 


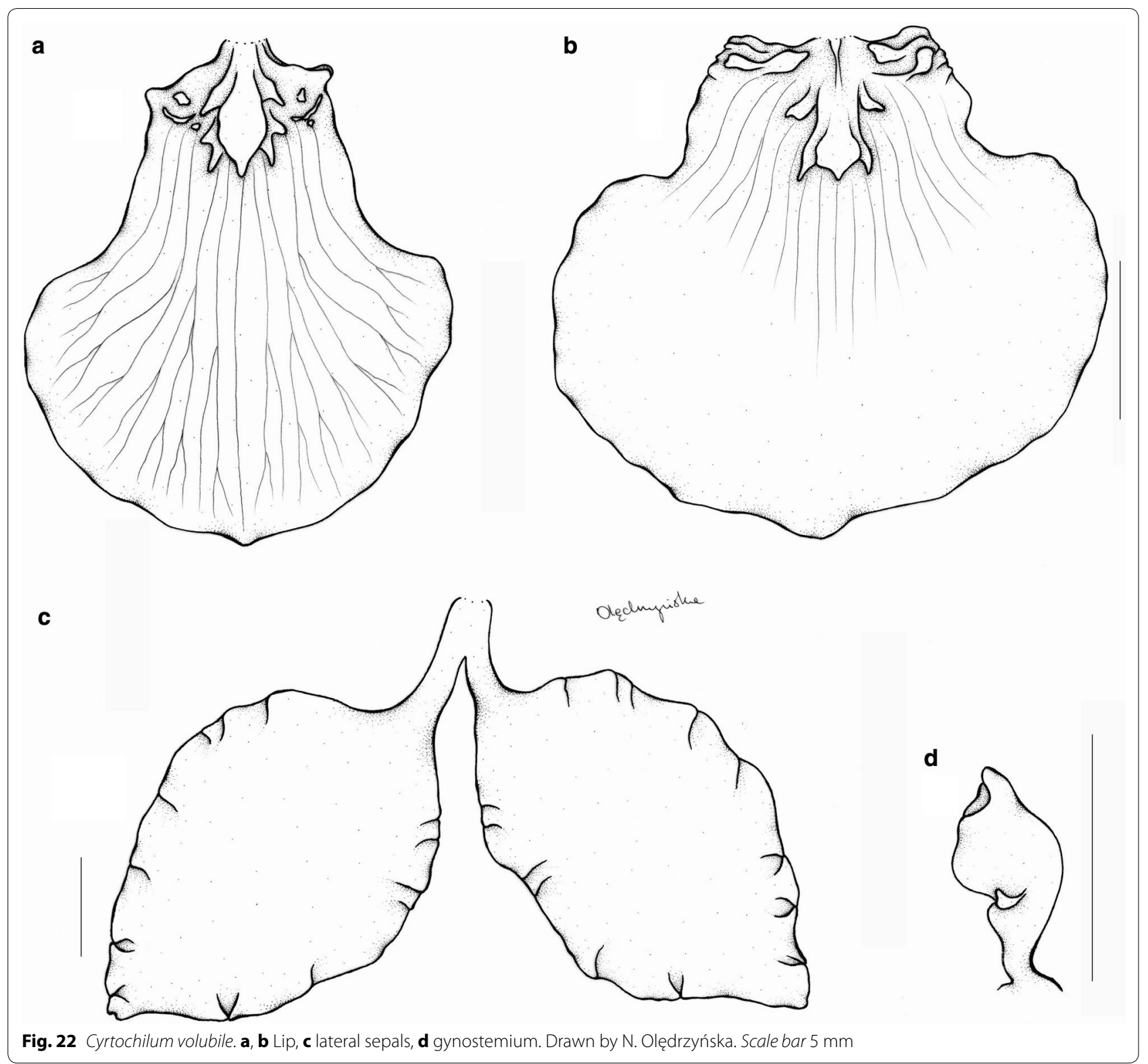

Basionym: Cyrtochilum tricornis Dalström \& RuízPérez, Lankesteriana 12(3): 151. 2012. Type: Peru. Cusco, Quillabamba, Rio Chullapi Reserva. Valenzuela et al. sub

Dalström et al. 2699 (Holotype: CUZ).

Trigonochilum koenigerii Szlach., Kolan. \& Chiron, sp. nov. (Figs. 23, 24).

The species is similar to T. cimiciferum and T. midas, but easily separable from both by the flower color, which is brown or brownish, and complicated lip callus. Additionally, it differs from $T$. cimiciferum by oblong elliptic-obovate, acute petals and large subquadrate stigma, from $T$. midas by acute lip.
Type: COLOMBIA. Dept. Putumayo. Valle de Sibundoy. Vereda San Pablo Bajo en Km 3 lado izquierdo de la carretera. Cult. R. Medina 325 (Holotype: MEDEL!).

Pseudobulbs about $7 \times 4 \mathrm{~cm}$, oblong-cylindrical, apically attenuate, almost rounded in cross section, unifoliate, enclothed basally by 4-6, large, leafy bracts. Leaves up to $38 \times 3.5 \mathrm{~cm}$, linear-oblanceolate to linear-oblong, acute, attenuate towards the base. Inflorescence basal, very long, with short, fractiflex, laxly few-flowered branches. Floral bracts 6-8 $\mathrm{mm}$ long, ovate-elliptic, obtuse. Pedicellate ovary about $28 \mathrm{~mm}$ long, almost straight. Flowers brown or brownish with 


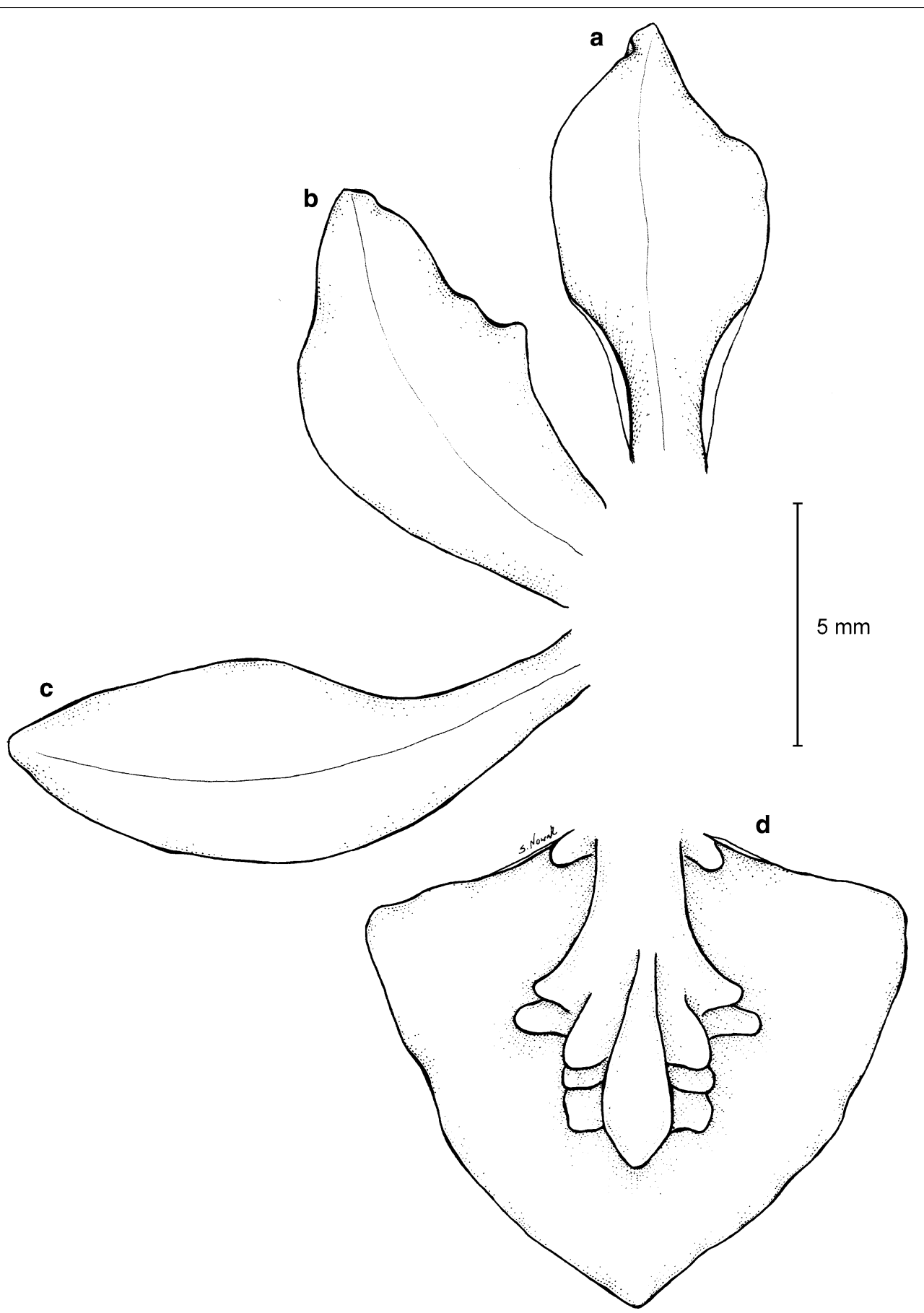

Fig. 23 Trigonochilum koenigerii-dissected perianth. a Dorsal sepal, b petal, c lateral sepal, d lip. Drawn by S. Nowak from the holotype

yellow apices of the petals and yellow lip callus. Sepals free, subequal, spreading. Dorsal sepal about $10 \times 5 \mathrm{~mm}$, concave, unguiculate, elliptic-oblanceolate, subacute. Lateral sepals $13 \times 6 \mathrm{~mm}$, obliquely spathulate, elliptic-oblanceolate, subobtuse, distinctly clawed. Petals $11 \times 0.8 \mathrm{~mm}$, oblong elliptic-obovate, acute, sessile. Lip sessile, $9.7 \times 11 \mathrm{~mm}$, entire, convex, widely triangular to ovate-triangular, acute; disc with a fleshy, complicated callus occupying the basal $2 / 3$ and two subglobose thickenings at the base. Gynostemium elongated, slightly sigmoid, slender, forming a right angle with the lip.

Etymology: Dedicated to Willibald Königer, German orchidologist who contributed to our knowledge and understanding of Oncidiinae. 

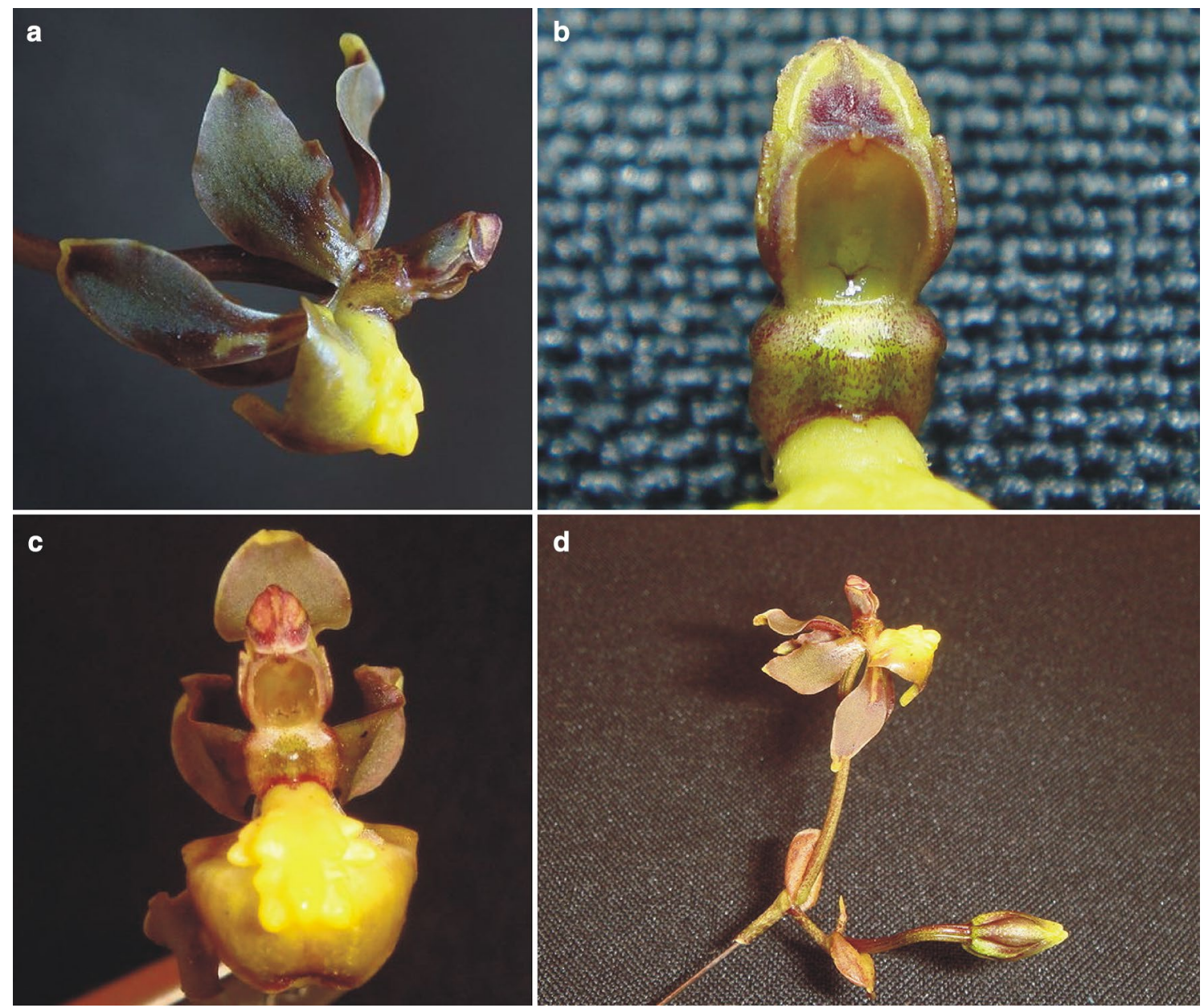

Fig. 24 Trigonochilum koenigerii. a Flower (side view), b gynostemium, c flower (front view), d fragment of the inflorescence. Photos: R. Medina

Table 1 Comparative morphology of Trigonochilum cimiciferum, T. koenigerii, and T. midas

\begin{tabular}{|c|c|c|c|}
\hline Character & T. cimiciferum & T. koenigerii & T. midas \\
\hline Pseudobulbs & Rounded-ovoid, $5-8$ × 1.5-2.5 mm & Oblong-cylindrical, $7 \times 4 \mathrm{~cm}$ & Ovoid, $4-10 \times 2-3 \mathrm{~cm}$ \\
\hline Leaves & Narrowly ovate, $20-40 \times 1.5-3 \mathrm{~cm}$ & $\begin{array}{l}\text { Linear-oblanceolate to linear-oblong, } \\
38 \times 3.5 \mathrm{~cm} \text { wide }\end{array}$ & Elongate-obovate, acuminate, up to $65 \times 2 \mathrm{~cm}$ \\
\hline $\begin{array}{l}\text { Pedicellate } \\
\text { ovary }\end{array}$ & $10-30 \mathrm{~mm}$ & About $28 \mathrm{~mm}$ & Up to $20 \mathrm{~mm}$ \\
\hline Flower & $\begin{array}{l}\text { Brownish-yellow with brown spots, } \\
\text { with yellow lip callus }\end{array}$ & Brown with yellow lip callus & $\begin{array}{l}\text { Almost completely white with whitish to yellow lip } \\
\text { callus }\end{array}$ \\
\hline Sepals & $\begin{array}{l}\text { Spathulate to rotundate, rounded- } \\
\text { acute, acute or acuminate }\end{array}$ & $\begin{array}{l}\text { Unguiculate to spathulate, elliptic- } \\
\text { oblanceolate, subacute or subob- } \\
\text { tuse }\end{array}$ & Spathulate, ovate, acuminate \\
\hline Petals & $\begin{array}{l}\text { Subsessile, obovate-elliptic to nar- } \\
\text { rowly obovate or oblanceolate, } \\
\text { acute }\end{array}$ & $\begin{array}{l}\text { Subsessile, oblong elliptic-obovate, } \\
\text { acute }\end{array}$ & Subsessile, ovate, acuminate \\
\hline Lip & $\begin{array}{l}\text { Ovate, ovate-triangular to elliptic- } \\
\text { obovate; disc with a fleshy callus in } \\
\text { the basal half }\end{array}$ & $\begin{array}{l}\text { Widely triangular to ovate-triangular; } \\
\text { disc with a fleshy, complicated callus } \\
\text { in the basal } 2 / 3 \text { and two subglobose } \\
\text { thickenings at the base }\end{array}$ & $\begin{array}{l}\text { Cordate to truncate; callus a central, longitudinal, } \\
\text { fleshy structure, extending from the base to } 2 / 3 \text { of } \\
\text { the disc length, terminating in digitate knobs or } \\
\text { denticles }\end{array}$ \\
\hline
\end{tabular}


Distribution and habitat: So far, the new species is known exclusively from the Colombian department of Putumayo. It was found growing in disturbed humid montane forest at about $2400 \mathrm{~m}$ a.s.l. In cultivation, it flowered in November.

Taxonomic notes: The new species is similar to $T$. cimiciferum (Rchb.f. ex Lindl.) Königer from which it differs on the basis of the brown flowers with a yellow lip callus (vs brownish-yellow flowers with brown spots), a complicated lip callus and oblong elliptic-obovate, acute petals. In petal shape, the new species resembles Ecuadorian $T$. midas from which it is easily separable not only in terms of the flower color (almost completely white with a yellow lip callus in T. midas) and acute lip (vs lip apiculate), but also the significantly longer ovaries (Table 1).

\section{Incertae sedis}

The position of "C. edwardii" and "C. cf. porrigens" in the phylogenetic tree is in conflict with results of morphological study, what we discuss above. Partial influence of Dasyglossum genetic material can not be excluded in both cases. Because morphological congruence of aforementioned species to other Trigonochilum representatives we propose to maintain them temporarily in this genus.

\section{Additional files}

Additional file 1: Appendix S1. Specimens of Cyrtochilum s.l. and Odontoglossum examined during the studies.

Additional file 2: Appendix S2. List of the features used in the phenetical study.

Additional file 3: Appendix S3. GenBank accession numbers for analysed sequences.

\section{Authors' contributions}

DLS: designing research, morphological data collection, data analysis, data interpretation, writing manuscript. MK: morphological data collection, data analysis, data interpretation, writing manuscript. AN: molecular analysis, writing manuscript, data interpretation. MG: molecular analysis, writing manuscript. MD: molecular analysis. PR: phenetical analysis, writing manuscript. GC: morphological data collection, data interpretation. All authors read and approved the final manuscript.

\section{Author details}

1 Department of Plant Taxonomy and Nature Conservation, The University of Gdańsk, ul. Wita Stwosza 59, 80-308 Gdańsk, Poland. ${ }^{2}$ Department of Biodiversity Research, Global Change Research Institute AS CR, Bèlidla 4a., 603 00 Brno, Czech Republic. ${ }^{3}$ Department of Molecular Evolution, The University of Gdańsk, Wita Stwosza 59, 80-308 Gdańsk, Poland. ${ }^{4}$ Herbiers, Université de Lyon I, 69622 Villeurbanne Cedex, France.

\section{Acknowledgements}

The lead author wishes to express his gratitude to the owner and staff of Ecuagenera (Ecuador), Peruflora (Peru) and Orquivalle (Colombia) for their hospitality during fieldwork and access to their rich orchid collections. We are grateful to Dr. Henrik Pedersen and Dr. Finn N. Rasmussen (Copenhagen University) for their comments and suggestions. We are also grateful to Ecuagenera, G. Deburghgraeve, E. Hunt and R. Medina T. for providing photos of the Cyrtochilum-complex species. We wish to thank Sławomir Nowak for preparing the illustration of new Trigonochilum species and to Mario Camilo Barrera G. and Ramiro Medina T. for their cooperation during the studies and providing information about habitat of the new species.

\section{Competing interests}

The authors declare that they have no competing interests.

\section{Funding}

The project has been supported by the Polish Ministry of Science and Higher Education (research Grant No. 8124/B/PO1/2011/40), European Commission's Research Infrastructure Action via the SYNTHESYS Project (GB-TAF-2445) and the Foundation for Polish Science (Fundacja na rzecz Nauki Polskiej, FNP).

Received: 2 June 2016 Accepted: 8 January 2017

Published online: 13 January 2017

\section{References}

Arft AM, Ranker TA (1998) Allopolyploid origin and population genetics of the rare orchid Spiranthes diluvialis. Am J Bot 85:110-122

Arnheim N, Krystal M, Schmickel R, Wilson G, Ryder O, Zimmer E (1980) Molecular evidence for genetic exchanges among ribosomal genes on nonhomologous chromosomes in man and apes. Proc Natl Acad Sci USA 77:7323-7327

Asmussen CB, Dransfield J, Deickmann V, Barfod AS, Pintaud J-C, Baker WJ (2006) A new subfamily classification of the palm family (Arecaceae): evidence from Plastid DNA. Bot J Linn Soc 151:15-38

Ayliffe MA, Timmis JN (1992) Tobaco nuclear DNA contains long tracts of homology to chloroplast DNA. Theor Appl Genet 85:229-238

Ayliffe MA, Scott NS, Timmis JN (1998) Analysis of plastid DNA-like sequences within the nuclear genome of higher plants. Mol Biol Evol 15:738-745

Bates JM, Cadena CD, Tello JG, Brumfield RT (2008) Diversification in the neotropics: phylogenetic patterns and historical processes. Ornitol Neotrop 19:427-432

Bergthorsson U, Richardson AO, Young GJ, Goertzen LR, Palmer JD (2004) Massive horizontal transfer of mitochondrial genes from diverse plant donors to the basal angiosperm Amborella. Proc Natl Acad Sci USA 101:17747-17752

Bermingham E, Moritz C (1998) Comparative phylogeography: concepts and applications. Mol Ecol 7:367-369

Brummitt RK (2006) Am I a bony fish? Taxon 55:268-269

Buerkle CA, Rieseberg LH (2008) The rate of genome stabilization in homoploid hybrid species. Evolution 62:266-275

Bullini L, Cianchi R, Arduino P, de Bonis L, Mosco MC, Verrardi A, Porretta D, Corrias B, Rossi W (2001) Molecular evidence for allopolyploid speciation and a single origin of the western Mediterranean orchid Dactylorhiza insularis (Orchidaceae). Biol J Linn Soc 72:193-201

Chase MW, Soltis DE, Soltis PS, Rudall PJ, Fay MF, Hahn WJ, Sullivan S, Joseph J, Givnish T, Sytsma KJ, Pires JC (2000) Higher-level systematics of the monocotyledons: an assessment of current knowledge and a new classification. In: Wilson KL, Morrison DA (eds) Systematics and evolution of monocots. CSIRO, Collingwood

Cheung WY, Scott NS (1989) A contiguous sequence in spinach nuclear DNA is homologous to three separated sequences in chloroplast DNA. Theor Appl Genet 77:625-633

Cook LM, Soltis PS, Brunsfeld SJ, Soltis DS (1998) Multiple independent formations of Tragopogon tetraploids (Asteraceae): evidence from RAPD markers. Mol Ecol 7:1293-1302

Cozzolino S, Aceto S (1994) Morphological and molecular characterization of Orchiaceras bergonii (Nanteuil) E. G. Cam. G Bot Ital 128:861-867

Cozzolino S, Widmer A (2005) The evolutionary basis of the reproductive isolation in Mediterranean orchids. Taxon 54:977-985

Cozzolino S, Aceto S, Caputo P, Menale B (1998) Characterization of Orchis $\times$ dietrichiana Bogenh., a natural orchid hybrid. Plant Biosyst 132:71-76

Cuénoud P, Savolainen V, Chatrou LW, Powell M, Grayer RJ, Chase MW (2002) Molecular phylogenetics of Caryophyllales based on nuclear 18S rDNA and plastid rbcL, atpB, and matK DNA sequences. Am J Bot 89:132-144 
Dalström S (2001) New species and combinations in the Oncidiinae (Orchidaceae) and a synopsis of the Cochlioda clade (Oncidiinae). Selbyana 22:135-145

Dalström S (2010) Cyrtochilum Kunth. In: Dodson CH, Luer CA (eds) Flora of Ecuador 225(3): Orchidaceae; genera Cyrtochiloides-Epibator. Department of Plant and Environmental Sciences, University of Gothenburg, Gothenburg

Domański Z, Kęsy J (2005) Distribuition of Manhattan distance in square and triangular lattices. Sci Res Inst Math Comput Sci 4:34-37

Douzery EJP, Pridgeon AM, Kores P, Linder HP, Kurzweil H, Chase MW (1999) Molecular phylogenetics of Diseae (Orchidaceae): a contribution from nuclear ribosomal ITS sequences. Am J Bot 86:887-899

Doyle JJ (1997) Within trees: genes and species, molecules and morphology. Syst Biol 46:537-553

Doyle JJ, Kanazin V, Schoemaker RC (1996) Phylogenetic utility of histone H3 intron sequences in the perennial relatives on the soybean (Glycine: Leguminosae). Mol Phylogenet Evol 6:438-447

Dressler RL (1981) The Orchids-natural history and classification. Harvard University Press, Cambridge

Edgar RC (2004) MUSCLE: multiple sequence alignment with high accuracy and high throughput. Nucleic Acids Res 32:1792-1797

Ellis J (1982) Promiscuous DNA-chloroplast genes inside plant mitochondria. Nature 299:678-679

Enea V, Corredor V (1991) The evolution of plasmodial stage-specific rRNA genes is dominated by gene conversion. J Mol Evol 32:183-186

Erixon P, Svennblad B, Britton T, Oxelman B (2003) Reliability of Bayesian posterior probabilities and bootstrap frequencies in phylogenetics. Syst Biol 52:665-673

Felsenstein J (1985) Confidence limits on phylogenies: an approach using the bootstrap. Evolution 39:783-791

Fitch WM (1971) Towards defining the course of evolution: minimum change for a specific tree topology. Syst Zool 20:406-416

Friesen N, Fritsch RM, Blattner FR (2006) Phylogeny and new intrageneric classification of Allium L. (Alliaceae) based on nuclear ribosomal DNA ITS sequences. Aliso 22:372-395

Galtier N, Gouy M, Gautier C (1996) SEAVIEW and PHYLO_WIN: two graphic tools for sequence alignment and molecular phylogeny. Comput Appl Biosci 12:543-548

Garay LA (1974) On the systematics of the monopodial orchids II. Bot Mus Lealf Harv Univ 23:369-376

Goldman DH, Jansen RK, van den Berg C, Leitch IJ, Fay MF, Chase MW (2004) Molecular and cytological examination of Calopogon (Orchidaceae, Epidendroideae): circumscription, phylogeny, polyploidy, and possible hybrid speciation. Am J Bot 91:707-723

Grant V (1981) Plant speciation. Columbia University Press, New York

Hammer $\varnothing$, Harper DAT, Ryan PD (2001) PAST: Paleontological Statistics Software Package for Education and Data Analysis. Palaeontol Electronica 4:1-9

Hedrén M (1996) Genetic differentiation, polyploidization and hybridization in northern European Dactylorhiza (Orchidaceae): evidence from allozyme markers. Plant Syst Evol 201:31-55

Hedrén M (2001) Systematics of the Dactylorhiza euxina/incarnata/maculata polyploidy complex (Orchidaceae) in Turkey: evidence from allozyme data. Plant Syst Evol 229:23-44

Hewitt GM (2001) Speciation, hybrid zones and phylogeography_or seeing genes in space and time. Mol Ecol 10:537-549

Hillis DM, Dixon MT (1991) Ribosomal DNA: molecular evolution and phylogenetic inference. Q Rev Biol 66:411-453

Hillis DM, Moritz C, Porter CA, Baker RJ (1991) Evidence for biased gene conversion in concerted evolution of ribosomal DNA. Science 251:308-310

Huang CY, Grunheit N, Ahmadinejad N, Timmis JN, Martin W (2005) Mutational decay and age of chloroplast and mitochondrial genomes transferred recently to angiosperm nuclear chromosomes. Plant Physiol 138:1712-1733

Jersáková J, Johnson SD, Kindlmann P (2006) Mechanisms and evolution of deceptive pollination in orchids. Biol Rev 81:219-235

Königer W (1996) Portillia-eine neue Gattung in der Subtribus Pleurothallidinae, neue Arten der Gattungen Portilia, Odontoglossum, Oncidium, Sigmatostalix, Trichocentrum und Trigonochilum. Arcula 6:154-185

Königer W (1999) Neue Arten der Gattungen Dracula, Masdevallia, Oncidium, Sigmatostalix und Trigonochilum. Arcula 8:218-249
Königer W (2000) Neue Arten der Gattungen Masdevallia, Oncidium, Sigmatostalix and Trigonochilum. Arcula 10:266-280

Königer W (2008) Neue Arten der Gattungen Oncidium und Scelochilus. Arcula 16:376-391

Königer W (2010) Neue Arten der Gattungen Oncidium und Trigonochilum. Arcula 19:422-437

Königer W, Schildhauer H (1994) Dasyglossum and Trigonochilum -two new genera in subtribus Oncidiinae. Arcula 1:1-28

Kores PJ, Molvray M, Weston PH, Hopper SD, Brown AP, Cameron KM, Chase MW (2001) A phylogenetic analysis of Diurideae (Orchidaceae) based on plastid DNA sequence data. Am J Bot 88:1903-1914

Kraenzlin F (1917) Cyrtochilum. Notizbl Bot Gart Berl Dahl 7:81-101

Lefébure T, Douady CJ, Gouy M, Gibert J (2006) Relationship between morphological taxonomy and molecular divergence within Crustacea: proposal of a molecular threshold to help species delimitation. Mol Phylogenet Evol 40:435-447

Linder CR, Rieseberg LH (2004) Reconstructing patterns of reticulate evolution in plants. Am J Bot 91:1700-1708

Maddison W (1997) Gene tress in species trees. Syst Biol 46:523-536

Madhulatha TS (2012) An overview on clustering methods. IOSR J Eng 2(4):719-725

Mallet J (2007) Hybrid speciation. Nature 446:279-283

Molvary MP, Kores PJ, Chase MW (2000) Polyphyly of mycoheterotrophic orchids and functional influences on floral and molecular characters. In: Wilson KL, Morrison DA (eds) Monocots: systematics and evolution. CSIRO, Collingwood

Neubig KM, Whitten WM, Williams NH, Blanco MA, Endara L, Burleigh JG, Silvera K, Cushman JC, Chase MW (2012) Generic recircumscriptions of Oncidiinae (Orchidaceae: Cymbidieae) based on maximum likelihood analysis of combined DNA datasets. Bot J Linn Soc 168:117-146

Nordal I, Stedje B (2005) Paraphyletic taxa should be accepted. Taxon 54:5-6

Nylander JAA (2004) MrModeltest v2. Program distributed by the author. Evolutionary Biology Centre, Uppsala University, Uppsala

Otto SP, Witton J (2000) Polyploid incidence and evolution. Annu Rev Genet 34:401-437

Pandit S, Gupta S (2011) A comparative study on distance measuring approaches for clustering. IJORCS 2:29-31

Paun O, Forest F, Fay MF, Chase MW (2009) Hybrid speciation in angiosperms: parental divergence drives peloidy. New Phytol 182:507-518

Pridgeon AM, Chase MW, Cribb PJ, Rasmussen FN (2009) Genera Orchidacearum, vol 5: Epidendroideae (part two). Oxford University Press, Oxford

Ramsey J, Schemske DW (1998) Pathways, mechanisms, and rates of polyploidy formation in flowering plants. Annu Rev Ecol Syst 29:467-501

Richter M, Diertl K-H, Emck P, Peters T, Beck E (2009) Reasons for an outstanding plant diversity in the tropical Andes of Southern Ecuador. Landsc Online 12:1-35

Rieseberg LH (1997) Hybrid origins of plant species. Annu Rev Ecol Syst 28:359-389

Rieseberg LH (2001) Chromosomal rearrangements and speciation. Trends Ecol Evol 16:351-358

Rieseberg LH, Sinervo B, Linder CR, Ungerer M, Arias DM (1996) Role of gene interactions in hybrid speciation: evidence from ancient and experimental hybrids. Science 272:741-745

Rogers SO, Bendich AJ (1987) Ribosomal RNA genes in plants: variability in copy number and in the intergenic spacer. Plant Mol Biol 9:509-520

Ronquist F, Huelsenbeck JF (2003) MrBayes 3: Bayesian phylogenetic inference under mixed models. Bioinformatics 19:1572-1574

Rosenberg NA (2002) The probability of topological concordance of gene trees and species trees. Theor Popul Biol 61:225-247

Sang T, Zhong Y (2000) Testing hybridization hypotheses based on incongruent gene trees. Syst Biol 49:422-424

Schaal BA, Hayworth DA, Olsen KM, Rauscher JT, Smith WA (1998) Phylogeographic studies in plants: problems and prospects. Mol Ecol 7:465-474

Schiestl F, Cozzolino S (2008) Evolution of sexual mimicry in the orchid subtribe Orchidinae: the role of preadaptations in the attraction of male bees as polinators. BMC Evol Biol 8:27

Senghas K (2001) Nachtraege 19. Tribus Oncidieae. Schlechter, Die Orchideen, Ed.3, Vol.1c, Lieferung 44/45:2784-2810

Senghas K (2003) Aus dem Beiratsressort Wissenschaft, Neues zur Gattung Odontoglossum. Journal fuer den Orchideenfreund 10:277-286 
Seperack P, Slatkin M, Arnheim N (1988) Linkage disequilibrium in human ribosomal genes: implications for multigene family evolution. Genetics 119:943-949

Small RL, Ryburn JA, Cronn RC, Seelanan T, Wendel JF (1998) The tortoise and the hare: choosing between noncoding plastome and nuclear Adh sequences for phylogeny reconstruction in a recently diverged plant group. Am J Bot 85:1301-1315

Soltis DE, Soltis PS (1999) Polyploidy: recurrent formation and genome evolution. Trends Ecol Evol 14:348-352

Stace CA (1989) Plant taxonomy and biosystematics. 2nd edn. Edward Arnold, Cambridge

Stegemann S, Keuthe M, Greiner S, Bock R (2012) Horizontal transfer of chloroplast genomes between plant species. Proc Natl Acad Sci USA 109:2434-2438

Swofford DL (2002) PAUP*: phylogenetic analysis using parsimony (*and Other Methods). Version 4. Sinauer Associates, Sunderland

Szlachetko DL (1995) Systema Orchidalium. W. Szafer Institute of Botany, Polish Academy of Sciences, Kraków

Szlachetko DL, Mytnik-Ejsmont J (2009) Gynostemia Orchidalium Vol. 4. Orchidaceae - Vandoideae. Acta Bot Fenn 180:1-313

Tremblay RL, Ackerman JD, Zimmerman JK, Calvo RN (2005) Variaton in sexual reproduction in orchids and its evolutionary consequences: a spasmodic journey to deversification. Biol J Linn Soc 84:1-54

Tsai CC, Chiang YC, Huang SC, Chen CH, Chou CH (2010) Molecular phylogeny of Phalaenopsis Blume (Orchidaceae) on the basis of plastid and nuclear DNA. Plant Syst Evol 288:77-98
Tyteca D, Klein E (2008) Genes, morphology and biology-the systematics of Orchidinae revisted. J Eur Orchid 40:501-544

Ungerer MC, Baird SJE, Pan J, Rieseberg LH (1998) Rapid hybrid speciation in wild sunflowers. Proc Natl Acad Sci USA 95:11757-11762

van der Cingel NA (2001) An atlas of orchid pollination: America, Africa, Asia and Australia. A. A. Balkema, Rotterdam

van der Pijl L, Dodson CH (1966) Orchid flowers: their pollination and evolution. University of Miami Press, Coral Gables

Vriesendorp B, Bakker FT (2005) Reconstructing patterns of reticulate evolution in angiosperms: what can we do? Taxon 54:593-604

Wendel JF (2000) Genome evolution in polyploids. Plant Mol Biol 42:225-249

Wendel JF, Schnabel A, Seelanan T (1995) Bidirectional interlocus concerted evolution following allopolyploid speciation in cotton (Gossypium). Proc Natl Acad Sci USA 92:280-284

Won H, Renner S (2003) Horizontal gene transfer from flowering plants to Gnetum. Proc Natl Acad Sci USA 100:10824-10829

Wu Cl (2001) The genic view of the process of speciation. J Evol Biol 14:851-865

Yuan Q, Hill J, Hsiao J, Moffat K, Ouyang S, Cheng Z, Jiang J, Buell CR (2002) Genome sequencing of a 239-kb region of rice chromosome $10 \mathrm{~L}$ reveals a high frequency of gene duplication and a large chloroplast DNA insertion. Mol Genet Genomics 267:713-720

Zimmer EA, Martin SL, Beverley SM, Kan YW, Wilson AC (1980) Rapid duplication and loss of genes coding for the alpha chains of hemoglobin. Proc Natl Acad Sci USA 77:2158-2162

\section{Submit your manuscript to a SpringerOpen ${ }^{\circ}$ journal and benefit from:}

- Convenient online submission

- Rigorous peer review

- Immediate publication on acceptance

- Open access: articles freely available online

- High visibility within the field

- Retaining the copyright to your article

Submit your next manuscript at springeropen.com 